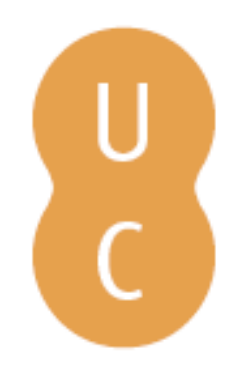

\title{
nombalina
}

\section{Las Navas de Tolosa (1212): a Batalha dos Quatro Reis}

Autor(es): $\quad$ Monteiro, João Gouveia; Martins, Miguel Gomes; Agostinho, Paulo Jorge

Publicado por: Imprensa da Universidade de Coimbra

URL persistente:

URI:http://hdl.handle.net/10316.2/37384

DOI:

DOI:http://dx.doi.org/10.14195/978-989-26-1023-8_2

Accessed : $\quad$ 26-Apr-2023 13:18:31

A navegação consulta e descarregamento dos títulos inseridos nas Bibliotecas Digitais UC Digitalis, UC Pombalina e UC Impactum, pressupõem a aceitação plena e sem reservas dos Termos e Condições de Uso destas Bibliotecas Digitais, disponíveis em https://digitalis.uc.pt/pt-pt/termos.

Conforme exposto nos referidos Termos e Condições de Uso, o descarregamento de títulos de acesso restrito requer uma licença válida de autorização devendo o utilizador aceder ao(s) documento(s) a partir de um endereço de IP da instituição detentora da supramencionada licença.

Ao utilizador é apenas permitido o descarregamento para uso pessoal, pelo que o emprego do(s) título(s) descarregado(s) para outro fim, designadamente comercial, carece de autorização do respetivo autor ou editor da obra.

Na medida em que todas as obras da UC Digitalis se encontram protegidas pelo Código do Direito de Autor e Direitos Conexos e demais legislação aplicável, toda a cópia, parcial ou total, deste documento, nos casos em que é legalmente admitida, deverá conter ou fazer-se acompanhar por este aviso. 


\title{
GUERRA E PODER NA EUROPA MEDIEVAL \\ DAS CRUZADAS \\ À GUERRA DOS 100 ANOS.
}

\author{
JOÃO GOUVEIA MONTEIRO \\ COORD.
}

\section{MIGUEL GOMES MARTINS \\ PAULO JORGE AGOSTINHO}

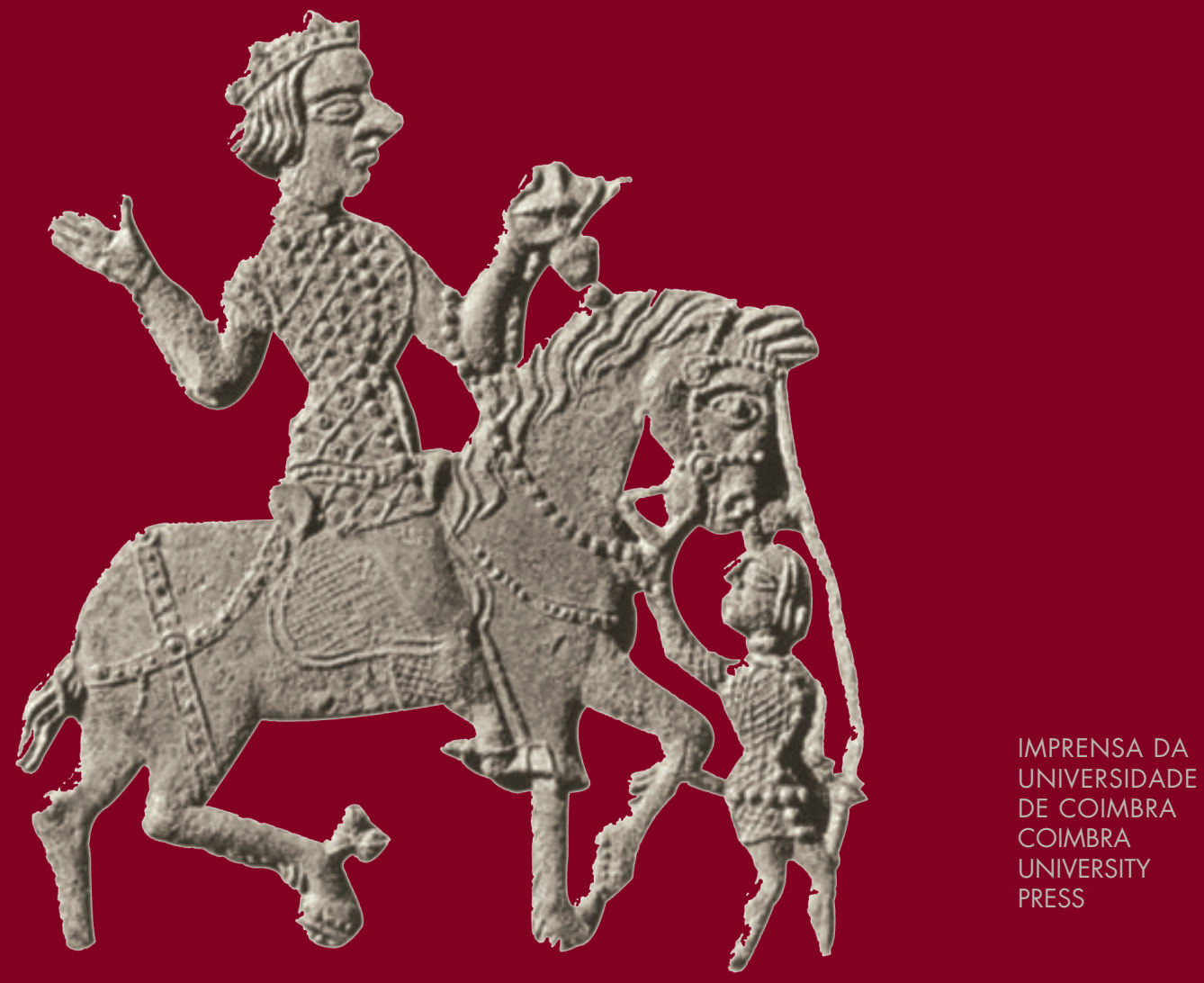




\section{LAS NAVAS DE TOLOSA (1212): \\ A BATALHA DOS QUATRO REIS}

\section{Um breve olhar sobre os avanços e recuos da Reconquista cristã}

Iniciada no ano de 711 pelas forças comandadas por Tarik ibn Ziyad - um destacado oficial do governador de África e do Magrebe, Musa ibn Nusayar - e continuada através de diversas campanhas lideradas pelo próprio governador e pelo seu filho, Abd al Aziz, a conquista muçulmana da Península Ibérica foi dada por concluída em 716, com a submissão de praticamente todo o antigo reino visigodo. Os territórios recém-conquistados foram então colocados sob a autoridade de um governador, ou wali, designado primeiro pelos califas Omíadas de Damasco e, depois, em inícios da década de 750, pelos Abássidas sedeados em Bagdade. Contudo, em 756, sob a liderança de Abderramão I, o al-Andalus - designação dada às regiões

peninsulares dominadas pelos muçulmanos - tornou-se um emirato (mais tarde califado) independente com o centro político na cidade de Córdova, facto que contribuiu fortemente para o seu desenvolvimento e prosperidade ao longo dos séculos IX e X.

O que restou dos exércitos visigodos, derrotados em diversas campanhas - designadamente na que teve como momento alto a Batalha de Guadalete (711), onde morreu o rei Rodrigo — , tinha conseguido refugiar-se, tal como muitos outros homens e mulheres, a norte, na zona montanhosa da antiga Cantábria, onde foi fundado, talvez ainda durante a década de 720, o pequeno reino das Astúrias, assim designado até à transferência 
da capital de Oviedo para Leão, em inícios do século X. Timidamente, a resistência cristã começa então a assumir uma postura mais ofensiva e 114 a ameaçar os territórios dominados pelo Islão, avançando também contra algumas regiões que até então se encontravam em poder de caudilhos de fronteira ou sem o controlo de qualquer autoridade político-militar. São avanços lentos mas que, não obstante, ajudam a consolidar cada vez mais a posição do - agora, assim designado — reino de Leão.

O desmembramento do Califado de Córdova, pulverizado logo a partir dos primeiros anos do século XI em pequenos reinos independentes, as taifas, veio alterar substancialmente o equilíbrio político-militar até aí existente na Península Ibérica entre cristãos e muçulmanos. É precisamente este contexto de fragmentação e consequente enfraquecimento do al-Andalus que irá permitir às forças de Afonso VI de Leão (1065-1109) avançar de forma fulgurante até à linha do Tejo, levando a cabo, em 1085, a conquista da cidade de Toledo, antiga capital do reino visigodo da Hispânia. Pela primeira vez desde 711, a balança pendia claramente para o lado dos exércitos oriundos do Norte. Foi, no entanto, uma supremacia de muito curta duração.

Conscientes da situação frágil em que se encontravam, alguns dos reinos taifas decidem pedir ajuda militar à dinastia magrebina dos Almorávidas, cujos contingentes, desembarcados em Algeciras em junho de 1086 e coligados, entre outros, com os exércitos sevilhanos de al-Mutamid, a que se somou o apoio de forças provenientes das cidades de Málaga e de Badajoz, infligem uma pesada derrota à hoste leonesa na Batalha de Zalaca (ou Sagrajas), ferida no dia 23 de outubro desse mesmo ano, nas imediações de Badajoz.

Só que os Almorávidas tinham planos bem mais ambiciosos. E assim, nos anos seguintes, através de diversas campanhas - algumas das quais com a presença do próprio emir Yusuf ibn Tashufin -, os exércitos norte-africanos conseguem submeter a maior parte dos reinos taifas, assenhorando-se dessa forma de quase todo o al-Andalus.

Face à imparável maré invasora, os finais do século XI e os anos iniciais da centúria seguinte são marcados por um abrandamento do processo reconquistador, que só volta a dar passos decisivos a partir de meados 
da década de 1140 (conquistas de Santarém, Lisboa, Calatrava e Almeria, por exemplo), em boa medida graças ao enfraquecimento do poder almorávida e ao novo período de taifas que lhe sucedeu.

Mas não são apenas os reinos cristãos (sobretudo Leão, Aragão e Portugal) que se aproveitam deste novo momento de turbulência interna no al-Andalus. Com efeito, do lado de lá do Estreito de Gibraltar, perfilava-se uma outra ameaça constituída pelos Almóadas, uma confederação de tribos berberes imbuídas de um forte zelo religioso, que entre 1130 e 1147 consegue dominar todo o Magrebe, afastar de vez a dinastia dos Almorávidas e, sob a liderança do seu primeiro califa, Abd al-Mumin, iniciar o processo de expansão para a Península Ibérica.

Fundada por Ibn Tumart, o ideólogo do movimento, e liderada após a sua morte, em 1130, por Abd al-Mumin — que se afirmava descendente de Maomé - , a confederação de tribos dos Almóadas consegue em apenas oito anos (1130-1138) dominar toda a região norte-africana do Atlas. O seu avanço é imparável e, nos sete anos seguintes, submetem praticamente todo o Magrebe, pondo fim ao poder almorávida, cujo emir, Abu Muhammad Tashufin, seria morto no cerco a Oran, em março de 1145.

Controlando unicamente a capital, Marraqueche, a dinastia cessante teria ainda outros dois soberanos — o filho e o irmão do emir —, embora todos soubessem que era apenas uma questão de tempo até que a cidade capitulasse. Com efeito, após a sua conquista, em março de 1147, a dinastia dos Almorávidas era definitivamente substituída pela dos Almóadas, a partir daí os novos senhores do Norte de África.

A desmilitarização e desorganização político-militar do al-Andalus, primeiro em resultado da necessidade de transferência de tropas almorávidas para o Norte de África e, depois, em consequência da morte do emir Abu Muhammad Tashufin, permitira, como vimos já, o surgimento e afirmação de diversos pequenos reinos independentes, as chamadas segundas taifas.

O primeiro sinal dessa nova fragmentação surge ainda no verão de 1144, quando as forças de Ibn-Qasi, um místico com pretensões a Messias e líder do movimento muridine, conquistam o castelo de Mértola proclamando a independência face aos Almorávidas. Juntam-se-lhe, pouco depois, Évora 
e Silves, que reconhecem também a autoridade do líder da revolta, e, pouco tempo depois, por conquista, as cidades de Beja, Huelva e Niebla. O alvo 116 seguinte foi Sevilha, cujo cerco terminou em novembro desse ano, com os atacantes rechaçados pelo governador almorávida Ibn Ghanya.

O falhanço do ataque à capital andaluza seria apenas o primeiro de uma série de revezes sofridos pelos revoltosos. De facto, em 1145, perdem as praças-fortes de Mértola e de Beja, deixando também de contar com o apoio militar de Évora, o que talvez tenha contribuído para o falhanço do cerco à cidade de Córdova. Toda esta sucessão de acontecimentos adversos levou Ibn-Qasi a fugir para Silves e a lançar um pedido de ajuda militar aos Almóadas, que por essa altura se preparavam para avançar sobre Marraqueche. Primeiro, através de uma carta, e, depois, pessoalmente, durante o início do outono de 1145, o líder da revolta acabará finalmente por ver o seu apelo aceite por Abd al-Mumin. Perante uma proposta que, para todos os efeitos, lhe abria as portas do al-Andalus, o califa aceita fornecer-lhe um exército - cuja dimensão e constituição se desconhece - mas impondo-lhe como contrapartida a condição de colaborar com essas forças na conquista de Sevilha, o prémio exigido por Abd al-Mumin.

Sob o comando do general Barraz al-Massufi, os primeiros contingentes almóadas desembarcam na Península durante a primavera de 1146, recebendo desde logo o apoio do almirante da frota estacionada em Cádis, o mesmo que, um ano antes — já em rota de colisão com os Almorávidas —, tinha proporcionado a Ibn-Qasi a viagem ao Norte de África. Apoderam-se de Tarifa e, seguidamente, de Algeciras, o que lhes garantia uma testa-de-ponte para o desembarque de novos contingentes e, ao mesmo tempo, uma base de operações para a ocupação militar subsequente das praças-fortes de Jerez, Niebla, Silves, Beja e Mértola, mas também de Santarém, que, mesmo não tendo sido tomada pela força, terá reconhecido a autoridade dos Almóadas, ou mesmo - ainda em 1145 - a de Ibn Qasi. O alvo seguinte, como havia sido exigido pelo califa, foi a cidade de Sevilha, conquistada em janeiro de 1147, depois de um apertado bloqueio terrestre e naval. Em pouco mais de um ano e sem o envolvimento de um grande número de forças recorde-se que o grosso das tropas norte-africanas se concentrava no cerco 
a Marraqueche, que cairia apenas em março desse ano - , os Almóadas e os seus aliados dominavam já, à exceção de Lisboa, todo o Gharb. Sem grande oposição, a ofensiva, como ironiza Bernard Reilly, parecia mais uma parada do que uma campanha militar propriamente dita (Reilly, 1996: 260).

A chegada e implantação dos novos senhores do al-Andalus não provocou, no imediato, um desequilíbrio de forças assinalável, por um lado porque os Almóadas depararam com importantes focos de resistência entre as comunidades muçulmanas peninsulares e, por outro, porque os exércitos dos reinos cristãos não deixaram nunca de exercer, embora com resultados práticos nem sempre expressivos, uma intensa pressão sobre a fronteira meridional. Porém, esta pressão não obedeceu nunca a uma estratégia concertada entre as coroas castelhana, leonesa - separadas em duas entidades autónomas na sequência da morte do imperador Afonso VII —, aragonesa, navarra e portuguesa, mas sim aos objetivos próprios de cada um desses reinos, que, não raras vezes, encontraram nos muçulmanos os aliados ideais para combater as pretensões territoriais e as tentativas hegemónicas dos seus vizinhos cristãos. Recorde-se, por exemplo, a aliança firmada entre Fernando II de Leão e os Almóadas, em 1169, contra Afonso Henriques e Geraldo, “O Sem-Pavor”; ou as tréguas de 1190, firmadas entre leoneses, castelhanos e muçulmanos, que permitiram ao califa lançar uma devastadora campanha contra o território português.

Ainda assim, a espaços, os reinos cristãos formaram também alianças entre si, com vista a uma oposição mais efetiva ao inimigo muçulmano. Assim foi, por exemplo, em 1183, com Castela e Leão a assinarem um tratado de paz com vista a uma conjugação de esforços contra os Almóadas; ou em 1184, quando portugueses e leoneses se uniram para fazer frente ao exército do califa Abu Yaqub Yusuf I, al-Sahid, que cercava Santarém; ou no verão de 1195, quando os reinos de Leão, Navarra, Portugal e Castela se aliaram para fazer frente a uma grande ofensiva conduzida pelos muçulmanos em retaliação pela construção, por Afonso VIII, do castelo de Alarcos, na fronteira sul castelhana.

De facto, no início de junho, o califa Abu Yusuf - que sucedera a seu pai, morto às portas de Santarém em agosto de 1184 - desembarca em 
Tarifa e entra em Sevilha ao comando de um poderoso exército. Era por demais evidente que nos seus planos estava a realização de uma campanha 118 tão devastadora quanto a que, cinco anos antes, tinha reconquistado aos portugueses - à exceção do enclave de Évora - todos os territórios situados a sul do rio Tejo. Foi justamente da capital andaluza que o califa partiu com a sua hoste em direção ao norte, atingindo o Campo de Calatrava no dia 4 de julho. Consciente dos riscos a que o seu reino estava exposto, Afonso VIII de Castela convoca a hoste para a cidade de Toledo e, imediatamente após solicitar o apoio militar leonês e português, avança para sul, decidido a travar a ameaça inimiga. Porém, sem aguardar pela chegada das hostes dos seus aliados, que se encontravam ainda em marcha, embora já com a participação de algumas forças portuguesas, o monarca castelhano decide enfrentar o adversário em batalha campal.

O prélio teve lugar no dia 18 de julho, junto do castelo de Alarcos, precipitado pela chegada dos Almóadas ao campo de batalha antes da altura prevista por Afonso VIII, que entretanto tinha posicionado as suas forças junto daquela fortaleza. Disposto a resolver rapidamente a questão e sem esperar pelos prometidos efetivos leoneses, o excessivamente confiante monarca castelhano abandona a posição onde se encontra e lança - talvez de forma pouco coesa e desorganizada - uma primeira carga de cavalaria contra a formação inimiga. Apesar de recebido pelas habituais e bem-sucedidas manobras de fuga simulada e chuvas de projéteis, o avanço dos cavaleiros cristãos atinge violentamente o corpo central do dispositivo tático inimigo. Contudo, as linhas muçulmanas são rapidamente recompostas graças ao apoio das forças da vanguarda e da sua ala direita. Ato contínuo, os contingentes da ala esquerda almóada realizam uma manobra de envolvimento pelo flanco e atacam o acampamento cristão posicionado na colina de Alarcos, caindo de seguida sobre a retaguarda do exército inimigo. A bem sucedida manobra da cavalaria andaluza é completada pelo avanço da retaguarda almóada, comandada pessoalmente pelo califa e cuja intervenção virá a constituir o golpe de misericórdia na hoste castelhana, cuja resistência era, assim, definitivamente aniquilada. 
Ao ver o desastre que se desenrolava à frente dos seus olhos, Afonso VIII ainda tentou, como um mártir, morrer em combate, mas foi "bruscamente resgatado" do campo de batalha e posto a salvo por alguns dos seus homens, que o levaram em segurança para Toledo.

Desbaratado o exército castelhano, Abu Yusuf - que assim ganhava o cognome que o haveria de celebrizar: al-Mansur, ou seja "O Vitorioso" - avança de imediato contra o castelo de Alarcos, cercando-o e arrasando-o após obter a sua capitulação. Nos dias seguintes, os Almóadas ocupam ainda as fortalezas de Torre de Guadalerza, Malagón, Benavente e Caracuel, ações com as quais encerram a fulgurante campanha de 1195.

As ofensivas muçulmanas dos anos subsequentes souberam tirar grande partido desta vitória, conquistando um conjunto significativo de praças-fortes até então controladas pelos castelhanos. Estes, profundamente fragilizados pela derrota e acossados também pelos vizinhos leoneses e navarros - que não hesitaram em aproveitar a sua debilidade para se apossar de importantes extensões territoriais -, tiveram que se remeter a uma postura eminentemente defensiva durante mais de uma década. Mas o desfecho da Batalha de Alarcos não se refletiu apenas em Castela, levando também a que as restantes monarquias cristãs abrandassem o seu processo reconquistador, ora em resultado das alianças firmadas depois de 1195 com os norte-africanos, ora por se sentirem incapazes de lhes fazerem frente. De facto, seria preciso esperar até ao ano de 1210 para se assistir novamente a uma grande e bem-sucedida ofensiva contra o sul muçulmano. Era o primeiro sinal de que algo estava prestes a mudar.

Contudo, a mais expressiva vitória militar sobre os exércitos almóadas teria lugar apenas em 1212, quando uma hoste encabeçada por Afonso VIII (e constituída por largos milhares de efetivos oriundos de todos os reinos cristãos peninsulares e reforçada ainda por um grande número de combatentes ultramontanos) infligiu uma pesada derrota ao exército do califa Abu Abd Allah Muhammad, al-Nasir, o filho e sucessor de Abu Yusuf, al-Mansur. O desfecho da batalha, ocorrida no dia 16 de julho no campo de Las Navas de Tolosa, teve um impacto tal que os seus ecos rapidamente ultrapassaram as fronteiras peninsulares, chegando a quase todos os cantos 
da cristandade e dando origem a um grande número de relatos e de notícias acerca do sucesso então obtido pela coligação liderada pelo rei de Castela.

\section{As fontes}

Ao contrário do que sucede com a maior parte das batalhas da Idade Média, Las Navas de Tolosa encontra-se bastante bem documentada. Num estudo recente, Martín Alvira (2012: 27) contabilizou, entre cronistas, analistas e trovadores cristãos medievais, cerca de 117 autores, mais de metade dos quais oriundos de fora do espaço peninsular (França, Ilhas britânicas, Alemanha, Itália e mesmo das regiões do Mediterrâneo oriental), reflexo da importância dada a esse acontecimento em toda a Europa cristã.

Claro está que uma boa parte dessas fontes foi produzida muitos anos depois da batalha, o que obriga, desde logo, a alguma cautela na sua utilização. Para além disso, muitas outras não passam de referências breves ou mesmo telegráficas e que, como tal, pouco ou nada adiantam à compreensão da forma como decorreu o combate. Existe, porém, um conjunto substancial de depoimentos que, ou por os seus autores terem sido intervenientes e testemunhas presenciais dos factos, ou mesmo porque deles tiveram conhecimento através de alguns dos que neles participaram, se revelam da maior importância para a compreensão e reconstituição, tanto dos acontecimentos ocorridos no dia 16 de julho, quanto de toda a campanha de 1212. De entre estes, os mais importantes e credíveis são os testemunhos diretos da batalha, ou seja, os relatos dos que nela estiveram presentes, e dos quais se destacam:

1- A carta de Afonso VIII ao papa Inocêncio III, informando-o da vitória obtida sobre as forças do califa e redigida poucas semanas depois, o que a torna uma fonte preciosa.

2- O De Rebus Hispaniae, uma crónica da autoria de Rodrigo Jiménez de Rada, arcebispo de Toledo e um dos grandes impulsionadores da campanha de Las Navas, na qual também participou, motivos 
mais que suficientes para que o seu depoimento seja considerado como um dos mais importantes. Dos 29 capítulos que o autor dedica ao governo de Afonso VIII, doze referem-se à campanha de 1212, o que faz desta obra um dos testemunhos mais detalhados dos acontecimentos.

3- A carta de Arnau Amalric, arcebispo de Narbonne, abade geral da Ordem de Cister e um dos líderes dos contingentes de cruzados ultramontanos, datada de 11 de agosto de 1212 e dirigida ao capítulo geral da Ordem de Cister, onde relata a campanha desse ano, na qual o prelado esteve presente. Foi precisamente este o texto que difundido através das inúmeras abadias cistercienses disseminadas por toda a Europa - mais fez pela divulgação dos ecos de Las Navas fora do espaço peninsular.

4- A carta do califa al-Nasir, lavrada escassos dias após a batalha, autêntico relato "oficial" almóada dos acontecimentos e onde, com um intuito claramente propagandístico, se procura escamotear a real dimensão da derrota. Se bem que silenciosa a respeito da forma como decorreu o prélio, não deixa de fornecer um útil conjunto de informações sobre a fase inicial da campanha.

Ainda que indiretas, dispomos também de um importante conjunto de fontes redigidas pouco tempo depois da batalha e por autores, de um modo geral, bem informados. De entre estas, merecem particular destaque:

1-A Carta de Berenguela, rainha de Leão e filha de Afonso VIII, dirigida à sua irmã Branca de Castela, mulher de Luís, o herdeiro da Coroa de França, dando-lhe conta da vitória cristã, da qual teve conhecimento através de missivas enviadas por seu pai.

2-A Carta de Branca de Castela para Branca, condessa de Champagne e irmã do rei de Navarra, Sancho VII, em que, sem grandes interpolações ou alterações, praticamente se transcreve o relato de Berenguela de Leão. 
3- A Chronica Regum Castellae (conhecida como Cronica Latina de los Reyes de Castilla), de Juan de Soria, figura que desempenhou as dignidades de abade de Santander e de Valladolid, de bispo de Osma, de Leão e de Burgos, para além de ser uma figura próxima de Afonso VIII de Castela e, mais tarde, de Fernando III, rei de Castela e Leão, de quem foi chanceler. Apesar de não ter participado na batalha, foi contemporâneo de todos esses acontecimentos, sobre os quais terá certamente recolhido informações junto de alguns dos intervenientes. Dos 22 capítulos dedicados ao reinado de Afonso VIII, mais de metade centram-se na campanha de 1212, tendo sido escritos, tudo o indica, pouco mais de 10 anos depois.

4- O Chronicon Mundi, de Lucas de Tuy, bispo da cidade galega de Tuy, que terá redigido a sua obra sob o patrocínio de Berenguela de Leão, entre 1230 e 1238. Dos doze capítulos dedicados ao reinado de Afonso VIII, quatro referem-se à batalha de Las Navas de Tolosa, apresentada, porém, sob uma perspetiva muito pessoal e claramente pró-leonesa dos factos, isto é, nem sempre favorável ao monarca castelhano, motivo pelo qual estudiosos como Huici Miranda não lhe concederam grande crédito. Ainda assim, o recurso a um interessante conjunto de informações coevas faz deste texto uma importante fonte para o estudo da batalha.

Para além destas - sem dúvida as mais importantes e, teoricamente, mais fidedignas - , existem ainda muitas outras fontes, algumas delas bastante posteriores, mas que, por vezes com um interessante grau de desenvolvimento, relatam o curso da batalha. É o caso da Estoria de España (c.1270/c.1289), habitualmente designada como Primera Cronica General de España, cuja redacção foi promovida por Afonso X, "o Sábio"; e também o da chamada Crónica de Veinte Reyes; apesar de seguirem ambas muito de perto o relato do arcebispo de Toledo, introduzem diversos dados novos, alguns deles bastante úteis para uma melhor compreensão dos factos.

Ainda que, na sua maioria, pouco ou nada adiantem sobre o modo como decorreu, algumas fontes narrativas muçulmanas revelam-se igualmente 
importantes para o estudo da batalha de Las Navas. É o caso, por exemplo, do Kitab al-anis al-mutib bi-Rawd al qirtás fi ajbar muluk al-Magrib, de Ibn Abi Zar, que, apesar de escrito na década de 1320 - ou seja, mais de cem anos depois dos factos - nem por isso deixa de ser bastante útil, ainda que a sua credibilidade tenha sido posta em causa, injustamente, reconheça-se, por alguns dos estudiosos da batalha.

Será, pois, alicerçado neste conjunto diversificado de fontes — se bem que com um maior peso daquelas que foram compostas pelos vencedores nos anos imediatamente posteriores à batalha, em especial por aqueles que nela participaram - que retomaremos uma viagem que nos conduzirá até ao campo de Las Navas de Tolosa e aos acontecimentos aí ocorridos no dia 16 de julho de 1212 .

\section{Da Paz à Guerra}

A derrota averbada em 1195, em Alarcos, bem como as devastadoras campanhas almóadas do ano seguinte, obrigaram os castelhanos a firmarem uma trégua com o inimigo. O acordo, assinado em agosto de 1197, seria posteriormente renovado em 1199 e em 1203, devendo vigorar até finais de 1210.

Mas as ameaças à fronteira castelhana não provinham apenas dos Almóadas, como se viu pelas reclamações territoriais e pelas incursões leonesas e navarras conduzidas imediatamente após a batalha de Alarcos. Assim, para evitar que a fragilidade provocada por aquela derrota continuasse a ser aproveitada pelos seus vizinhos cristãos para obterem ganhos territoriais à sua custa, em finais de 1197, Castela terá assinado uma outra trégua, desta feita com o reino de Leão - ao que parece, sob os auspícios de um legado papal —, com a duração de dez anos e que viria a ser renovada em 1209. Seguiram-se, em 1207, as tréguas com Navarra — assinadas em Guadalajara e que encerraram um longo período de guerra - , bem como a renovação da aliança com Aragão, acordada em Calatayud em 1198 e que abriu caminho para os acordos firmados onze anos depois entre aragoneses e navarros (García Fitz, 2008: 135-137). Ou seja, em 1209, tinha 
finalmente sido alcançada uma paz duradoura entre as diversas monarquias cristãs peninsulares.

124 Estes anos de relativa tranquilidade permitiram a Castela recuperar das derrotas anteriores, reorganizar a sua máquina de guerra e começar, aos poucos, a preparar-se para o final das tréguas com os Almóadas. Estes, pelo seu lado, beneficiaram também com este período de paz, porquanto ficaram com o caminho livre para a resolução de alguns problemas internos, designadamente para procederem à submissão dos últimos redutos almorávidas, por um lado com a conquista das ilhas Baleares, em 1203 e, por outro, com a ocupação da Ifríquia, no Norte de África, em 1205-1206. No auge do poder político-militar do império, o califa al-Nasir — que sucedera a Abu Yusuf al-Mansur em 1199 - podia agora voltar a dirigir a sua atenção para os teatros de operações da Península Ibérica.

Mas não eram apenas castelhanos e almóadas que, por essa altura, se preparavam para o final das tréguas. Com efeito, também o rei de Aragão, Pedro II, planeava retomar a ofensiva logo que possível. Porém, esse era um projeto que, para ser bem-sucedido, necessitava de contar com o apoio armado castelhano, algo que só podia ser conseguido caso Afonso VIII não renovasse os acordos de paz com os Almóadas. Por isso mesmo, logo em inícios de 1210 - ou seja, a escassos meses do final dessas tréguas -, o aragonês solicitou a Inocêncio III que pressionasse o monarca castelhano nesse sentido. Contudo, o papa limitou-se a remeter uma missiva ao arcebispo de Toledo, instando-o, bem como aos seus sufragâneos, para que exercessem a influência possível junto do rei de Castela para que este concedesse o seu apoio às ações militares aragonesas ou, pelo menos, para que autorizasse todos os castelhanos que assim o desejassem fazer a incorporar-se nas hostes de Pedro II.

Afonso VIII estava longe de pretender renovar as tréguas com os Almóadas, mas, ao contrário do seu homólogo aragonês, preferiu manter os planos em segredo, ganhando assim algum tempo para - sem que com isso suscitasse uma reação inimiga - poder implementar as medidas necessárias para retomar a ofensiva e, acima de tudo, para enfrentar uma mais que certa investida inimiga em larga escala. A sua primeira prioridade 
foi o reforço da fronteira, expressa no repovoamento, já em 1210, da praça-forte de Moya, na região de Cuenca.

Aquilo que, aparentemente, não passava de uma ação que visava a defesa de uma zona de fronteira foi, no entanto, imediatamente interpretada pelo califa al-Nasir como um ato hostil e, consequentemente, como uma autêntica declaração de guerra que levou ao rompimento automático das tréguas. À primeira vista, o rei castelhano parecia ter cometido um enorme erro. Porém, como sugere o cronista Lucas de Tuy (2003: 87), era precisamente esse o objetivo de Afonso VIII que, assim, acabava deliberadamente por fornecer um motivo para a quebra unilateral das tréguas por parte dos Almóadas, o que lhe dava a margem de manobra necessária para poder livremente retomar as hostilidades. E de facto, os ataques castelhanos à região a norte de Jaén e de Córdova parecem confirmar ser justamente esse o seu intuito.

Por seu lado, os aragoneses, que nos anos anteriores tinham igualmente reforçado algumas das suas posições mais avançadas, tomam também a iniciativa e intensificam a pressão na fronteira sul atacando a região de Valencia, onde conquistam diversos castelos - Ademuz, Castielfabib, El Cuervo e Serrella - um conjunto de operações que foram, muito provavelmente, programadas de forma a coincidirem com as ofensivas castelhanas, hipótese que parece sugerir que os dois reinos estavam a prosseguir já, e com sucesso, uma política articulada.

No entanto, por muito bem-sucedidas que tivessem sido essas campanhas, para inverter realmente os pratos da balança a favor dos reinos cristãos era fundamental pensar numa ação de maior envergadura, o que só seria possível caso contassem com a participação de Leão, de Navarra e de Portugal. Importava, pelo menos, assegurar que esses reinos nada fariam para dificultar as ações armadas castelhanas e aragonesas, já que era mais do que certa uma reação musculada do califa, à qual era imperioso resistir e responder de um modo firme. Foi justamente com esse objetivo que o herdeiro do trono castelhano, o infante D. Fernando, solicitou ao papa o envio à península de um legado apostólico com a missão de convencer Afonso IX, Sancho VII e Afonso II a participarem num projeto comum que unisse os esforços dos cinco reinos contra os Almóadas. Perante a recusa 
do papa, poucos meses depois, em finais de 1210 ou já em inícios de 1211, foi o próprio Afonso VIII a fazer o mesmo pedido a Inocêncio III. Todavia, 126 mais uma vez, o papa recusou fazê-lo. Não é fácil descortinar os motivos que levaram a essa tomada de posição por parte da Santa Sé, embora tanto Huici Miranda quanto Martín Alvira sugiram que na sua raiz estaria, não só a falta de vontade em compactuar com o mau relacionamento existente entre os diversos reinos cristãos peninsulares, mas também a circunstância de o papado se encontrar já envolvido em diversas outras frentes: na Cruzada contra os Albigenses, nos conflitos entre Capetos e Plantagenetas, e nos problemas que o opunham ao Imperador Romano-Germânico (Huici Miranda, 2000: 229; e Alvira Cabrer, 2012: 90-91).

Importa, no entanto, sublinhar que, apesar de não atender a esses pedidos da monarquia castelhana, nem por isso o papa deixou, em diversas ocasiões, de conceder algum apoio a Afonso VIII. Assim foi quando advertiu os reinos de Navarra e de Leão para que não violassem as tréguas firmadas com Castela, respetivamente em 1207 e em 1209, ou quando, na sequência da quebra das tréguas, em 1210, estendeu as indulgências habitualmente concedidas aos Cruzados a todos quantos participassem na luta contra os Almóadas, um apoio tímido, como o que entretanto havia concedido a Aragão, para onde o pontífice se limitou a enviar ajuda financeira destinada a algumas das campanhas conduzidas por Pedro II.

Claro que o silêncio da Santa Sé aos apelos do infante D. Fernando e de Afonso VIII não inibiu as forças cristãs de prosseguirem as suas incursões contra território inimigo, como a que, sob o comando do rei de Castela e do seu herdeiro, alcançou Levante e Játiva na primavera de 1211, ou a que, pela mesma altura, foi liderada por Afonso Teles de Menezes e por Rodrigo Rodriguez, os quais, com o apoio das milícias concelhias de Toledo, reconquistaram a fortaleza de Torre de Guadalerza, perdida na sequência da batalha de Alarcos.

Perante a crescente agressividade castelhana e aragonesa, em inícios de 1211, o califa, que se encontrava na capital do império, Marraqueche, resolve lançar um amplo e vigoroso apelo à Jihad, conseguindo com isso a mobilização de um numeroso exército que, embora assolado por diver- 
sos problemas - designadamente ao nível do abastecimento - , cruza o estreito de Gibraltar durante a segunda quinzena maio, avançando então para Sevilha, onde instala o seu quartel-general. Ainda que inicialmente o alvo fosse o território de Aragão - o cronista Ibn-Idari sugere mesmo que a reação do califa foi desencadeada em resposta à ameaça aragonesa, e não propriamente como retaliação pelas campanhas castelhanas al-Nasir muda de planos e opta por atacar as regiões mais próximas da sua base de operações, decidindo-se por uma das principais praças-fortes da fronteira castelhana, uma decisão de última-hora que parece confirmar as dificuldades logísticas sentidas logo desde o início da mobilização do exército em Marrocos.

O alvo escolhido foi, pois, o castelo de Salvatierra. Situado no extremo sul da região de La Mancha e já próximo do sopé da Sierra Morena, era controlado desde 1198 pela Ordem Militar de Calatrava, que aí tinha instalado - depois da perda de Calatrava la Vieja, na sequência da batalha de Alarcos - o seu principal convento, circunstância que o convertia numa das mais relevantes praças-fortes da linha avançada castelhana e na base de operações ideal para o lançamento de incursões contra o território inimigo. Não admira, pois, que os Almóadas o vissem, segundo Martin Alvira Cabrer (2012: 70-72), como uma autêntica "espinha cristã cravada em território islâmico". Além disso, importa não esquecer que as Ordens Militares não estavam sujeitas aos acordos de paz firmados pelas monarquias peninsulares, o que, mesmo em período de tréguas, fazia dessa fortaleza uma ameaça permanente.

$\mathrm{Na}$ perspetiva do califa, a conquista de Salvatierra era, pois, um objetivo prioritário que permitiria não apenas um alívio na pressão exercida pelo adversário, mas também um rude golpe nas aspirações expansionistas castelhanas. Mas a conquista daquela fortaleza significava igualmente a anulação do único obstáculo entre Sevilha e o vale do Tejo, cujos caminhos ficariam abertos para os Almóadas, que facilmente poderiam então atingir a capital castelhana de Toledo. Além do mais, ao avançar sobre Salvatierra, talvez al-Nasir conseguisse levar Afonso VIII a reagir intempestivamente e, quem sabe, a cair no erro de reunir a sua hoste e avançar até essa praça, 
o que, a acontecer, daria certamente azo a uma batalha campal na qual o califa ambicionava poder repetir o êxito de seu pai em Alarcos.

Mas os castelhanos devem, de alguma forma, ter percebido as intenções do adversário, pois ainda antes de o exército almóada se lançar sobre a fortaleza, tomaram a decisão de reforçar a sua guarnição e de a abastecer com grandes quantidades de mantimentos e de armas. Porém, optaram por deixá-la entregue à sua própria sorte, afastando desde logo a possibilidade da mobilização de um exército de socorro, uma ideia que, segundo o testemunho do arcebispo de Toledo, parece que chegou a ser proposta pelo rei que, no entanto, acabou por a pôr de parte reconhecendo que não era possível reunir, em tempo útil, uma força suficientemente numerosa para evitar a queda da fortaleza e, simultaneamente, fazer frente à hoste de al-Nasir (Livro VII, cap. XXXV, p. 305).

O cerco a Salvatierra foi iniciado em julho de 1211, com a destruição da povoação sobranceira ao castelo. Perante a avassaladora superioridade numérica do inimigo e sem grandes meios para retaliar, os defensores limitaram-se a responder com uma ou outra surtida, protagonizadas por forças de cavalaria mas que pouco efeito tiveram no ânimo do inimigo. Com os mantimentos e a água a esgotar-se, sem qualquer perspetiva de receberem ajuda do exterior e com a pressão a intensificar-se nas semanas seguintes, a moral dos sitiados esgotou-se quando os engenhos neurobalísticos dos sitiadores conseguiram, ao fim de cinquenta e um dias de cerco, abrir uma brecha nas muralhas. Sem outra opção, os sitiados acabaram por se render e entregaram a praça-forte ao califa, que, ao abrigo da preitesia acordada, autorizou os sobreviventes a partirem para o norte em segurança.

Em júbilo pela importante vitória alcançada, o exército almóada retornou então a Sevilha, dando assim por concluída a campanha desse ano.

A notícia, rapidamente difundida, da perda de Salvatierra teve um enorme impacto, não só na Península mas em todo o Ocidente, alertando para os perigos da ameaça muçulmana e para a eventualidade de uma ofensiva em larga escala que poderia facilmente atingir a capital castelhana e, em última análise, anular todo o processo reconquistador iniciado séculos antes. Mas a queda de Salvatierra trouxe rapidamente ao de cima um outro 
sentimento, o de vingança. Como afirma Francisco García Fitz (2008:143), estava encontrado "o catalisador emocional necessário para que se precipitasse a reação cristã”. Não havia já quaisquer dúvidas de que Castela se preparava para responder em força à ofensiva almóada.

Com efeito, logo após tomar conhecimento da perda de Salvatierra e ciente dos riscos que essa situação poderia comportar, o rei de Castela, através do bispo de Segovia, lança um apelo desesperado à Santa Sé para que fosse pregada uma Cruzada contra os Almóadas. Só que, desta vez, o pedido teve o eco desejado expressando-se no envio, durante as primeiras semanas de 1212, de instruções para todos os arcebispos de França, da Provença e respetivos sufragâneos, no sentido de anunciarem nas suas arquidioceses e dioceses a concessão de indulgências e a remissão de todos os pecados a quantos participassem na grande expedição que o rei de Castela começara a organizar. Pouco depois, novas missivas papais eram dirigidas aos arcebispos de Toledo e de Compostela, instando-os para que pressionassem os reis de Leão, de Aragão, de Navarra e de Portugal, por um lado, no sentido de ajudarem militarmente o seu congénere castelhano e, por outro, para que evitassem - sob pena de excomunhão - aliar-se aos Almóadas ou, pelo menos, para que nada fizessem que prejudicasse a ofensiva que então se preparava. O pontífice tinha a perfeita noção do sério risco de leoneses e navarros aproveitarem o facto de Afonso VIII se encontrar em campanha na fronteira sul para se lançarem contra o território de Castela. No entanto, por muito presente que fosse esse perigo, a maior ameaça era, sem dúvida, o enorme poder do exército almóada, pelo que o papa não deixou também de aconselhar o rei castelhano a, caso o califa propusesse um acordo de tréguas, aceitá-lo de imediato, já que não seria possível suportar um novo desastre como o que ocorrera anos antes em Alarcos (Alvira Cabrer, 2012: 88).

Mas por muito importante que fosse o apoio prestado pela Santa Sé, tanto no plano diplomático como financeiro, mas também ao nível da mobilização de forças de além-Pirenéus - que desde cedo e em força corresponderam ao apelo papal - Afonso VIII sabia que as hipóteses de sucesso face aos Almóadas seriam bem maiores se pudesse contar com o apoio armado dos seus vizinhos cristãos peninsulares. 
Quanto a Pedro II de Aragão, o castelhano estaria certamente tranquilo, pois tanto a aliança que vigorava entre ambos havia já vários anos quanto os 130 recentes acordos firmados em Cuenca, em novembro de 1211, asseguravam a sua colaboração, embora se soubesse que os problemas financeiros da Coroa aragonesa poderiam vir a constituir um entrave a uma participação militar com grande expressão. Foi, todavia, um problema que acabou por ser rapidamente resolvido, por um lado graças à ajuda financeira castelhana e, por outro, através de um empréstimo concedido por Sancho VII de Navarra que, dessa forma, parecia dar sinais de aproximação aos planos castelhanos.

Mas a posição navarra, ao contrário do que aquele empréstimo poderia indiciar, estava longe de ser a mais clara. De facto, a atitude inicial de Sancho VII, O Forte, foi a de alhear-se do projeto e, sem se comprometer, esperar para ver, em boa medida devido aos recentes conflitos com Castela, mas também por saber que uma derrota de Afonso VIII poderia beneficiá-lo com importantes ganhos territoriais. Além disso, um eventual apoio a esses planos poderia colocá-lo em rota de colisão com al-Nasir, com quem mantinha um acordo de paz, tal como o próprio califa fez questão de sublinhar na carta redigida depois da batalha (p. 334). Por tudo isso, não é de admirar que só alguns meses depois, em finais de junho, o posicionamento de Sancho de Navarra se tenha clarificado.

Igualmente complexa de gerir era a posição leonesa. Com efeito, o envolvimento direto de Afonso IX na guerra civil que eclodira em Portugal em finais de 1211 entre o rei Afonso II e as suas irmãs Teresa e Sancha, no âmbito da qual o rei leonês interveio em apoio destas últimas - em particular da sua ex-mulher Teresa, com quem fora casado entre 1191 e 1194 -, poderiam impedi-lo de acudir ao pedido de auxílio armado lançado por Afonso VIII. No entanto, Afonso IX até mostrou uma certa disponibilidade para integrar o projeto do seu velho rival, se bem que com a condição de lhe serem devolvidas algumas das fortalezas ocupadas por Castela, uma pretensão que não foi atendida - e a que não foi sequer dada qualquer resposta (García Fitz 2008: 147-148) —, o que, como seria de esperar, afastou de vez as hipóteses de os leoneses virem a integrar a expedição. Porém, este era um cenário que obrigava a cautelas redobradas com a retaguarda, 
pois havia o sério risco de os leoneses se aproveitarem da ausência de Afonso VIII para atacarem o território castelhano, como o próprio papa não deixou sublinhar em carta enviada a Afonso IX, exortando-o a que nada fizesse nesse sentido.

Teoricamente mais fácil seria conseguir o apoio do rei português, Afonso II, casado desde 1208 com Urraca, filha de Afonso VIII. No entanto, desde cedo que se percebeu que os problemas de saúde do monarca (talvez lepra), mas acima de tudo a guerra civil que desde finais de 1211 assolava o reino, obstaculizavam não só a que o rei português pudesse juntar-se à expedição como o impediam sobretudo de enviar alguns contingentes em apoio do sogro.

Ainda assim, isso não invalidou que, se bem que a título individual, muitos leoneses, bem como um grande número de portugueses (segundo Rodrigo Jiménez de Rada, cap. III, 309), seguissem o apelo do papa e se juntassem às forças que, a partir dos últimos dias de maio de 1212, começavam a afluir a Toledo, o local estipulado para a reunião dos contingentes envolvidos na campanha que, em boa medida pelo seu caráter internacional, assumia cada vez mais os contornos de uma autêntica Cruzada, conforme o objetivo de Afonso VIII (Alvira Cabrer, 2012: 84 e 92-96). De facto, como sublinhou Francisco García Fitz, toda a campanha de Las Navas se encontra rodeada dos "gestos, palavras, rituais, invocações, símbolos, imagens, interpretações, perceções" característicos de um ambiente de Cruzada, em boa medida propiciado pelo próprio Inocêncio III, que, na missiva de abril desse ano dirigida aos arcebispos de Toledo e de Santiago de Compostela, afirmava que o que estava em jogo era não apenas o destino dos reinos cristãos peninsulares, mas o da própria Cristandade (García Fitz, 2008: 438-440).

\section{À procura de uma batalha}

Se bem que a sequência dos acontecimentos pudesse de alguma forma apontar nesse sentido, o objetivo estratégico de Afonso VIII não era 
reconquistar Salvatierra, ou sequer recuperar as fortalezas perdidas para os Almóadas em 1195 e 1196, na sequência do desastre de Alarcos; do 132 mesmo modo, não pretendia persistir numa guerra de desgaste como a que caracterizava a maior parte das operações militares da Idade Média, muito particularmente na Península Ibérica; e também não era seu propósito lançar um ataque em diversas frentes - para forçar o adversário a dividir as suas forças - com o intuito de empurrar novamente a fronteira para sul. Em boa verdade, esses poderiam vir a constituir objetivos a médio e a longo prazo, mas no imediato a ideia do monarca castelhano era outra, bem diversa e consideravelmente mais ambiciosa. De facto, o plano de Afonso VIII consistia em infligir uma derrota tão expressiva e pesada quanto possível aos Almóadas, a ponto de reduzir substancialmente a sua capacidade militar, algo que, como todos sabiam, só poderia ser alcançado de uma forma: através de uma batalha campal. Tratava-se, no entanto, de uma solução que comportava enormes riscos - porquanto o resultado de uma batalha era sempre impossível de prever —, que exigia a mobilização de inúmeros recursos humanos e logísticos e que necessitava de contar com um inimigo disposto a aceitar o desafio, o que nem sempre acontecia. Por tudo isso, a batalha era quase sempre a últimas das opções dos comandantes militares, circunstância que fazia dela um fenómeno raro e episódico no contexto da guerra nos últimos séculos da Idade Média. Porém, o plano do monarca castelhano consistia precisamente em fazer o que ninguém esperava que ele fizesse, ou seja, procurar forçar os Almóadas a um combate em campo aberto. Certamente que esta decisão terá deixado muitos espantados, em parte porque o desfecho de Alarcos - que ninguém queria que se repetisse - estava ainda bem vivo na memória dos castelhanos, mas também porque, como sublinha García Fitz (2008: 87), nunca antes uma expedição militar tinha sido preparada com o único intuito de destruir o adversário em batalha campal!

Esta resolução parece ter sido tomada imediatamente após a queda de Salvatierra, quando o rei, reunido em Toledo com algumas das principais personalidades do reino, declarou pretender reunir os meios necessários para derrotar os Almóadas num enfrentamento em campo aberto. 
Com efeito, a ordem de mobilização emitida no dia 29 de setembro de 1211 - ou seja, apenas dois meses após a perda daquela fortaleza — refere já, de forma explícita, ser esse o objetivo da Cruzada (Alvira Cabrer, 2012: 82-83). Claro que, para isso, era necessário, em primeiro lugar, que o adversário estivesse disposto a fazê-lo; porém, os acontecimentos pareciam estar a correr a favor de Afonso VIII.

Apesar de se tratar de uma questão ainda envolta em inúmeras interrogações e incertezas, é possível que al-Nasir tenha respondido às ações de Afonso VIII com uma carta - o chamado "Desafio do Miramolim" - enviada aos monarcas cristãos e na qual os desafiava para uma batalha. Todavia, como o próprio califa fazia questão de sublinhar, essa missiva não constituía qualquer forma de reação à ordem de mobilização e aos objetivos inimigos, mas sim uma resposta às campanhas levadas a cabo por Afonso VIII na sequência da quebra das tréguas, em 1210, descartando dessa forma a possibilidade de estar a agir a reboque das decisões estratégicas do adversário.

Só que, em lugar de a manter secreta, o monarca castelhano deixou que tanto a carta quanto o seu conteúdo fossem dados de imediato a conhecer, pelo menos junto de boa parte dos líderes e combatentes cristãos, de modo a motivá-los ainda mais para a campanha que se avizinhava. Mas mesmo que - como defendem muitos dos estudiosos da batalha - não tenha existido qualquer repto por parte de al-Nasir, só o rumor da existência da missiva, propositadamente difundido pelo rei, terá sido suficiente para galvanizar ainda mais os Cruzados que começavam a afluir ao local combinado para a concentração dos exércitos cristãos (Alvira Cabrer, 2008: 111-119).

Com a reunião de todas as forças aprazada para os finais de maio ou inícios de junho, a chegada dos combatentes a Toledo tem início a partir da Oitava de Pentecostes, dia 20 de maio. Os primeiros Cruzados a fazê-lo são os efetivos aragoneses liderados pessoalmente por Pedro II, seguidos pelos ultramontanos, que fazem a sua entrada na capital castelhana no dia 3 de junho, totalizando mais de 50000 homens, de acordo com o depoimento do arcebispo de Narbonne, que comandava essas forças (p. 330). 
Entretanto, muitos outros contingentes - mesnadas nobres, Ordens Militares, milícias concelhias - foram também chegando à capital castelhana, que 134 cada vez mais se assemelhava a um acampamento militar. A presença de um número crescente de guerreiros obrigou mesmo Afonso VIII a alojá-los no exterior da cidade, não só pela necessidade de encontrar um espaço amplo para se instalarem, mas acima de tudo para evitar a repetição de desacatos, tumultos e atos violentos — como os que visaram a população judaica de Toledo - provocados por uma tão grande acumulação de gentes imbuídas de uma enorme vontade de combater, mas entre as quais se havia instalado um clima de tédio suscitado pela inatividade e pela demora no início da campanha (Carta de Arnau Amalric, p. 329). A todos os que necessitavam, o rei forneceu alojamento, armas, roupas, montadas, alimentos e remunerações, o que exigiu aos cofres e aos armazéns régios um enorme esforço, que tanto o próprio monarca quanto os cronistas não deixaram de referir nos relatos que elaboraram depois acerca da campanha de 1212 .

Por fim, na quarta-feira, dia 20 de junho, tem lugar a partida das forças cristãs, com a coluna de marcha dividida em três grandes unidades táticas: a vanguarda, cujo comando foi entregue ao veterano Diego Lopez de Haro e que integrava as forças ultramontanas; o corpo central da hoste, composto pelos efetivos aragoneses liderados por Pedro II, e a retaguarda constituída pelos contingentes castelhanos capitaneados por Afonso VIII (Rodrigo Jiménez de Rada, Livro VIII, cap. V, p. 312).

Porém, não eram apenas os Cruzados que se movimentavam em direção ao inimigo. De facto, por essa mesma altura, ou seja, nos primeiros dias de junho, também o exército almóada deixava Sevilha, estabelecendo a sua base de operações a leste, em Jaén, a partir de onde seria mais fácil acorrer e travar uma incursão lançada a partir de Toledo contra território andaluz, mas cujo trajeto e destino eram ainda desconhecidos (Huici Miranda, 2000: 249).

Apesar do que a carta de desafio sugeria, os verdadeiros planos de al-Nasir não passavam pela realização de uma batalha campal. Pelo contrário, todos os movimentos do exército califal - substancialmente reforçado ao longo da primavera de 1212 - revelam que o seu principal objetivo seria 
precisamente o de evitar o combate em campo aberto, mas sem que o adversário se apercebesse disso. Dessa forma, este seria obrigado a avançar cada vez mais em território hostil na perseguição daquele objetivo, afastando-se das suas principais bases de aprovisionamento e de apoio. Forçando-o a essa desgastante marcha, o califa esperava conseguir debilitar física e moralmente os combatentes cristãos, sujeitando-os aos problemas inerentes ao abastecimento de um exército de tão grandes dimensões como o que então tinha sido reunido, mas também a um trajeto desgastante e violento, feito sob o calor escaldante do verão andaluz (García Fitz, 2008: 92-93).

\section{Os primeiros confrontos}

Ao fim de quatro dias de marcha em direção a sul e sem qualquer contacto com o inimigo, a vanguarda da hoste dos Cruzados chega junto das muralhas de Malágón, uma vila e castelo situados a cerca de $90 \mathrm{~km}$ de Toledo. Mesmo sem o apoio do corpo central e da retaguarda da hoste, que se encontravam ainda em trânsito, os efetivos que compunham aquela unidade tática, integrada essencialmente por Cruzados ultramontanos, conquistam-na facilmente ao fim de poucas horas de combate (Carta de Afonso VIII, pp. 567-568). Os comandantes muçulmanos ainda tentaram, através de um acordo de rendição, salvaguardar as vidas dos que aí se encontravam, mas, perante a recusa dos atacantes em aceitá-lo, a fortaleza foi mesmo conquistada pela força e a esmagadora maioria dos sitiados acabou chacinada pelos Cruzados que, como afirma Arnau Amalric, pouparam apenas "uns poucos" (p. 330).

Porém, o ambiente festivo resultante da primeira vitória e do primeiro sangue mouro derramado rapidamente se esfumou, pois no dia 26, segunda-feira, com a hoste novamente reunida, começaram a vir ao de cima os problemas - característicos dos exércitos de grandes dimensões - relacionados com a escassez de mantimentos, um problema que, ainda assim, Afonso VIII conseguiu solucionar antes de partirem de Malagón, procedendo a uma nova distribuição de víveres pelos Cruzados. 
A expedição ainda estava no início e a falta de géneros começava já a fazer-se sentir e a provocar as primeiras querelas, desencadeadas, 136 sobretudo, pelos Cruzados ultramontanos.

No dia 27, o exército retoma a marcha em direção ao Guadiana, com o objetivo de avançar sobre o castelo de Calatrava que, desde 1158 e até ser conquistado pelos Almóadas, em 1195, tinha alojado a sede da Ordem de Calatrava. Contudo, a travessia do rio revelou-se bem mais difícil do que seria esperado, pois o inimigo tinha espalhado os temíveis "abrolhos" - cardos de metal com quatro pontas destinados a ferir os pés dos homens e os cascos dos cavalos - nos vaus do rio, esperando com isso dificultar-lhes a travessia e, assim, atrasar ou mesmo impedir que se aproximassem daquela fortaleza. No entanto, a armadilha foi detetada a tempo, o que, ainda assim, obrigou os batedores a procurarem uma passagem alternativa, que ao fim de algumas horas acabou por ser encontrada, possibilitando, ainda nesse dia, a travessia do Guadiana em total segurança.

Mas Calatrava estava longe de constituir um alvo fácil, devido às resistentes estruturas de defensivas da fortaleza, na sua maior parte erguidas ainda antes de 1195. O exército cristão corria o risco de se envolver numa operação de cerco para a qual não estava devidamente preparado, já que não dispunha dos meios necessários, nomeadamente de engenhos, para o fazer. Além disso, a arrastar-se por mais tempo do que o desejado, um ataque à praça-forte poderia colocar em xeque todo o calendário da campanha e os objetivos estratégicos de Afonso VIII, pelo que a possibilidade de um ataque acabou por ser logo posta de parte. Ainda assim, depois de dois dias de observação e de estudo do inimigo, os comandantes acharam por bem arriscar, pelo menos, um assalto em massa. A intensa pressão exercida simultaneamente por milhares de homens em diversos sectores das muralhas era tal que obrigou o comandante da guarnição muçulmana a propor uma rendição negociada, solução que Afonso VIII aceitou, sob o compromisso de poupar as vidas dos defensores. Cumprido o acordo, o castelo foi entregue ao rei castelhano, que, por sua vez, o fez retornar à posse dos freires da Ordem de Calatrava. 
E tal como tinha sucedido dias antes em Malagón, também esta vitória trouxe ao de cima novos problemas, designadamente os que eram levantados pelos Cruzados ultramontanos, que, desapontados com a escassez do botim, desgastados pela doença, pela fome e pelo clima estival do sul de Castela, mas também profundamente desiludidos pela forma, segundo eles, demasiado branda como tinha sido negociada a capitulação de Calatrava, acabam por abandonar a hoste. Apontando como motivos a falta de vontade de Afonso VIII em procurar um enfrentamento campal com o inimigo - o que teria defraudado as suas expetativas - os rumores a respeito de um alegado plano para desviar a Cruzada contra o reino de Leão, mas também o final do período de serviço de 40 dias a que se tinham comprometido, os ultramontanos iniciam, em massa, o regresso aos seus locais de origem. Como sublinhou García Fitz (2008: 94), a estratégia almóada de obrigar os cristãos a prolongar a sua presença em território hostil, com todos os problemas que daí advinham, nomeadamente ao nível da moral e do abastecimento, parecia estar a dar resultado. Embora a perda de cerca de um terço dos combatentes tenha, naturalmente, fragilizado o exército cristão e causado alguma inquietação e medo entre os que ficaram - ao ponto de se registarem novas deserções nos dias subsequentes —, a partida dos ultramontanos acabou por se revelar benéfica, porquanto permitiu solucionar os problemas de abastecimento com que a hoste se debatia, já que, com menos bocas para alimentar, era agora possível restabelecer algum equilíbrio no que concerne à distribuição dos mantimentos disponíveis.

Al-Nasir, que através de espiões e de outros informadores acompanhava de perto as movimentações dos inimigos e estava a par das dificuldades com que estes se defrontavam, logo que soube da debandada dos contingentes ultramontanos partiu de Jaén em direção à região a sul da Sierra Morena, para onde sabia que o que restava da hoste cristã acabaria por se dirigir.

Como se previa, no dia 4 de julho, o exército liderado por Afonso VIII afasta-se de Calatrava. Nessa praça-forte ficaria, no entanto, o rei Pedro II - acompanhado por alguns contingentes —, a aguardar pela chegada de mais algumas forças aragonesas, mas também pelo exército navarro liderado 
por Sancho VII. Este último, após muita indecisão, decidira juntar-se também à Cruzada, depois de ter sido convencido a integrá-la pelo arcebispo de 138 Narbonne, aquando da passagem dos Cruzados ultramontanos pela corte de "o Forte", a caminho de Toledo, em finais de maio.

Enquanto isso, os restantes corpos da hoste retomam a marcha e avançam contra as pequenas fortalezas de Alarcos, Piedrabuena, Benavente e Caracuel, conquistando a primeira e obtendo a rendição das restantes. No dia 7 de julho, já com todas as forças novamente reunidas e reforçadas pelos combatentes provenientes de Navarra, o exército inicia então a aproximação final à praça-forte de Salvatierra, cuja reconquista constituiria uma excelente motivação para o que restava da campanha. Mas Afonso VIII decidiu não correr riscos, pois sabia bem que uma operação de cerco, ou mesmo um assalto massivo menos bem-sucedido, poderiam atrasar ou até pôr em causa os objetivos da expedição. No entanto, numa manobra intimidatória e de clara demonstração de força conduzida propositadamente à vista da guarnição muçulmana da fortaleza, o monarca realiza um imponente alardo destinado a avaliar com rigor a dimensão e o estado das tropas. Juan de Soria afirma, sem adiantar quaisquer cifras, que "nunca tantas e tais armas de ferro se haviam visto em terras hispânicas" (p. 30), enquanto que a Crónica de Veinte Reyes - que também nada refere a respeito do número de combatentes então contabilizado, fazendo apenas eco da grande dimensão do exército ali reunido - acentua sobretudo a circunstância de a inesperada partida dos ultramontanos em nada ter debilitado a moral ou o poderio da hoste dos Cruzados (cap. XXIX, p. 283).

A marcha, retomada no dia 10 de julho, conduziu em primeiro lugar a vanguarda da hoste até Las Fresnedas, já no sopé da Sierra Morena. Foi no acampamento aí instalado que Diego Lopez de Haro - comandante dessa unidade - deu instruções ao seu filho, Lope Diaz, e aos seus sobrinhos, Sancho Fernandez e Martín Muñoz, para, ao comando de um forte destacamento, ocuparem o Porto do Muradal, na vertente norte da serra, e evitar que o inimigo se antecipasse e bloqueasse a passagem da hoste. Defendido o local, o destacamento avança então contra a pequena fortaleza de Ferral, em cujas imediações é surpreendido por batedores 
muçulmanos, que conseguem rechaçar. A porta de entrada na Sierra Morena estava assegurada.

No dia 12, ao entardecer, o grosso do exército chega finalmente ao 139 sopé da serra, reunindo-se apenas no dia seguinte às forças que controlavam o desfiladeiro do Muradal, tornado ainda mais seguro depois de a guarnição do castelo de Ferral se ter posto em fuga. Apesar dos êxitos dos últimos dias, designadamente o controlo dos acessos à serra, a hoste tinha ainda pela frente a difícil missão de percorrer os tortuosos caminhos que a levariam até ao Passo de Losa, ou seja, para sul dessa cadeia montanhosa. No entanto, rapidamente se percebeu que esse objetivo estava perto de redundar num fracasso. Com efeito, como puderam constatar os batedores cristãos, os Almóadas tinham instalado as suas forças precisamente nesse local, bloqueando-lhes por completo a saída do desfiladeiro.

Perante esta contrariedade, teve então lugar uma importante reunião do conselho de guerra dos Cruzados. Importava urgentemente decidir o que fazer: retroceder pelo mesmo trajeto que tinham acabado de percorrer e contornar a serra, ou arriscar a descida em direção ao Passo de Losa e enfrentar o inimigo? Enquanto a primeira opção obrigava a um desvio que demoraria vários dias, ou mesmo semanas, a recuperar, a segunda colocava os Cruzados numa clara posição de desvantagem e à mercê da hoste do califa, porquanto seriam obrigados a combater com uma frente de ataque pouco extensa, devido à estreiteza do terreno por onde teriam que passar. Como o próprio Afonso VIII afirmou mais tarde, na carta dirigida ao papa, tratava-se de uma passagem tão estreita que, se os muçulmanos assim o quisessem, bastaria colocarem aí 1000 homens, que nem assim os cristãos conseguiriam passar (p. 569).

Enquanto decorria a reunião do conselho de guerra de Afonso VIII que cada vez mais se inclinava, apesar de tudo, para a hipótese de arriscar uma progressão pelo Passo de Losa —, apresentou-se no acampamento cristão um homem - que a maior parte das fontes regista tratar-se de um pastor - , conhecedor dos caminhos da serra e que assegurou saber da existência de um trajeto alternativo (veja-se uma revisão recentíssima da figura deste pastor em Rafael Peinado Santaella, 2015). Para efetuar o reconhecimento 
desse percurso foram escolhidos os experientes Diego Lopez de Haro e Garcia Romeu, os quais, ao comando de um forte destacamento destinado 140 a prevenir qualquer armadilha, puderam confirmar a veracidade do testemunho do pastor e verificar com os próprios olhos que esse caminho, para além de permitir a passagem do exército em total segurança, desembocava numa zona ampla - mais tarde designada como Mesa del Rey - alguns quilómetros a oeste do Passo de Losa e, consequentemente, afastada das forças almóadas. Aí, o exército cristão, para além de poder instalar o seu acampamento, poderia ainda, sem quaisquer constrangimentos ditados pelo terreno, organizar livremente o seu dispositivo tático e defrontar o inimigo.

Depois de enviarem ao rei informações detalhadas sobre as condições proporcionadas por essa nova rota, o contingente liderado por Diego Lopez e Garcia Romeu ocupa uma posição no início do trajeto revelado pelo pastor, mas é de imediato alvo de ataques por parte de destacamentos inimigos. A muito custo, conseguem defendê-la e manter-se na sua posse até à chegada, já na manhã de sábado, dia 14, do grosso da coluna de marcha cristã.

O califa, quando soube que o inimigo abandonava o cume da serra, pensou tratar-se de uma retirada. O seu plano para desgastar o exército cruzado e obrigá-lo a retroceder parecia estar a resultar na perfeição e sem que para isso tivesse sido necessário travar uma batalha campal. Porém, para seu grande espanto, a hoste inimiga começava a surgir através de um outro desfiladeiro e a instalar-se na Mesa del Rey. Perante esta súbita reviravolta no rumo dos acontecimentos, os Almóadas abandonam de imediato a posição elevada que ocupam em Santa Elena e, preparados para o combate, deslocam-se para o Cerro de los Olivares, um local mais próximo da zona onde os Cruzados se começavam a instalar (García Fitz, 2008: 494-496). Porém, em virtude do enorme cansaço provocado por quase um mês de marcha, os cristãos preferiram adiar a contenda, resistindo a todas as provocações, ataques e escaramuças protagonizados pela cavalaria ligeira e pelos arqueiros muçulmanos.

No domingo, dia 15, al-Nasir volta a formar o seu exército em frente da Mesa del Rey, demonstrando que estava, uma vez mais, disposto e preparado para enfrentar o inimigo. No entanto, tal como na véspera, 
os cristãos evitam a batalha, ainda que constantemente pressionados pelos ataques conduzidos por diversos destacamentos de escaramuçadores almóadas.

Mas era impossível continuar a adiar mais o momento de defrontar o exército califal, pelo que, assim que raiou a alvorada de segunda-feira, dia 16 de julho de 1212, já todos sabiam que a batalha seria inevitavelmente travada nas horas seguintes. E sabiam também que, no final do dia, uma das hostes teria sido vergada sob o peso da derrota, embora ninguém pudesse ainda adivinhar a qual das duas estaria reservado esse destino cruel. Ambos os contendores dispunham de bons motivos para acreditar que poderiam ser eles a vencer o prélio; e sem dúvida que um dos principais argumentos com que contavam para alcançar a vitória era a composição e dimensão das respetivas hostes.

\section{Os exércitos em presença}

Como era comum nos grandes exércitos da Idade Média, também a hoste cristã presente em Las Navas de Tolosa se caracterizava por uma enorme heterogeneidade, não só ao nível da procedência geográfica dos seus efetivos (castelhanos, aragoneses, navarros, ultramontanos e ainda alguns leoneses e portugueses), mas também da sua estrutura interna e dos vários núcleos que a formavam, cada um deles com uma composição e uma dimensão muito próprias.

Em primeiro lugar, destacavam-se os séquitos dos reis, isto é, as forças que compunham as guardas pessoais de Afonso VIII de Castela, Pedro II de Aragão e Sancho VII de Navarra. Cada uma dessas unidades era integrada por contingentes de cavalaria e de infantaria, num total que rondava os 150 a 200 combatentes, que atuavam não apenas como uma guarda palaciana de proteção do monarca mas, acima de tudo, como uma autêntica "força de intervenção rápida" facilmente mobilizável, bem armada e dotada de um elevado grau de prontidão (García Fitz, 2008: 184-186), motivo pelo qual terão certamente sido das primeiras forças a serem convocadas para a campanha de 1212 . 
Mas eram as mesnadas senhoriais (ou seja, os contingentes dos grandes magnates laicos e eclesiásticos) que, somadas, constituíam o sector 142 numericamente mais expressivo do exército cruzado e, como tal, a sua 'coluna vertebral'. Só a nobreza castelhana terá contribuído, segundo a Crónica de Veinte Reyes, com perto de 2300 lanças de cavalaria, números que talvez não estejam demasiado desfasados da realidade (cap. XXVIII, p. 281). Trata-se, todavia, de uma cifra compreensivelmente superior às das suas congéneres aragonesa e navarra que, segundo as estimativas de Francisco García Fitz (2008: 210), não deverão ter ultrapassado, respetivamente, os 800 e os 200 cavaleiros. Cada uma dessas mesnadas era liderada por um fidalgo e formada por um núcleo central de lanças de cavalaria pesada — onde se integravam também os seus vassalos —, a que se somavam ainda forças de cavalaria ligeira e de infantaria, boa parte das quais provenientes dos senhorios do líder da mesnada ou dos seus vassalos.

Tal como a nobreza, também as Ordens Militares acorreram em massa ao apelo de Afonso VIII. Com efeito, em Las Navas estiveram presentes as Ordens de Calatrava, de Santiago, do Templo e do Hospital, integradas não só por freires cavaleiros, mas também por sergentes (combatentes de cavalaria equipados de forma mais ligeira) e por milícias concelhias procedentes das povoações jurisdicionalmente sujeitas a estas instituições, para além de outros combatentes voluntários e, em alguns casos, remunerados. Ainda que as fontes não permitam conhecer a dimensão desses contingentes, tudo aponta para que tenha sido um contributo de grande importância, porquanto eram lideradas pelas autoridades máximas dessas Ordens, ou seja, pelos respetivos mestres e prior (García Fitz, 2008: 186-200).

Igualmente importante — sobretudo pela quantidade de efetivos que assegurou - foi a participação das milícias concelhias, sobretudo das castelhanas, já que não há notícia da presença de forças dos concelhos aragoneses e navarros na batalha. Eram integradas, como habitualmente, por combatentes montados, sobretudo por ginetes (García Fitz, 2008: 211-218), num total que, de acordo com a Crónica de Veinte Reyes, terá rondado os 11700 cavaleiros (cap. XXVII, p. 281), números decerto muito inflacionados 
e que não devem sequer ter chegado aos 5000 homens, entre cavalaria e infantaria, um contributo ainda assim bastante expressivo.

Para além dos séquitos de Afonso VIII, Pedro II e Sancho VII, das mesnadas nobres castelhanas, aragonesas e navarras, das Ordens Militares do Templo, Hospital, Calatrava e Santiago e das milícias concelhias castelhanas, a hoste reunida em 1212 contava igualmente com um grande número de voluntários de origem geográfica e social muito diversa e que responderam em massa à Cruzada convocada por Inocêncio III. De entre esses guerreiros, destacavam-se os ultramontanos, provenientes, sobretudo, do reino de França, mas também da Península Itálica, num total que terá oscilado entre os 50000 homens estimados por um dos seus principais líderes, o arcebispo Arnau Amalric (p. 330), e os 62000 aventados na carta de Afonso VIII (p. 567). Contudo, como já vimos, só uma pequena parte desses efetivos escolheu permanecer com a hoste até ao final da campanha, pelo que, dessas largas dezenas de milhares de combatentes, aqueles que de facto participaram na batalha de Las Navas devem oscilado entre os 130 cavaleiros aventados por Jiménez de Rada (Livro VIII, cap. VI, p. 315) e as 150 lanças referidas por Afonso VIII na missiva dirigida ao papa (p. 568); a estes se somava decerto um grupo bastante elevado, embora desconhecido, de forças de infantaria. Aos voluntários ultramontanos acrescentava-se ainda um contingente, provavelmente substancial, de leoneses e também de portugueses - muitos cavaleiros e uma "multidão" de infantes, nas palavras do arcebispo de Toledo (Livro VIII, cap. II, p. 309) - que, apesar de os seus reinos não terem oficialmente participado na Cruzada, nem por isso deixaram de se juntar aos efetivos reunidos na cidade de Toledo a partir dos finais de maio de 1212 .

Com cifras parciais, quase sempre exageradas e pouco fiáveis, como as que são veiculadas pelas fontes disponíveis, torna-se praticamente impossível reconstituir com rigor a dimensão da hoste cristã presente em Las Navas. Ainda assim, apesar dessas dificuldades, foram vários os estudiosos que adiantaram algumas hipóteses. Um dos primeiros autores contemporâneos a pronunciar-se a esse respeito foi o francês Ferdinand Lot, que, em 1946, sugeriu uma estimativa na ordem dos 2000 cavaleiros e 6000 a 7000 peões, 
ou seja, um total que mal chegaria aos 10000 combatentes (Lot, 1946: 289-290). Uma década depois, Ambrosio Huici Miranda (1956/2000: 271) 144 propunha - embora com algumas reticências - cifras bastante mais generosas a respeito da dimensão do exército cristão que, segundo ele, totalizaria entre 60000 e 80000 homens. Apesar de se tratar de números que o próprio autor considerou que devem ser encarados com bastante cautela, acabaram por ser aceites por boa parte dos estudiosos da batalha, nomeadamente por Francisco García Fitz, que em 2001, numa primeira abordagem do tema, os considerou como bastante verosímeis (2001: 364).

Contudo, nem todos adotaram os cálculos de Huici Miranda. Em 1984, Ruiz Doménech (1984: 586) aproximava-se de Ferdinand Lot com uma cifra na ordem dos 10000 guerreiros, enquanto Hernàndez Cardona, em 2002, sugeria uma estimativa bastante mais generosa, na ordem dos 25000 a 30000 homens (2002: 63), próxima da de Kelly DeVries, que em 2007 aventou a hipótese de o exército liderado por Afonso VIII rondar os 27000 efetivos, entre cavaleiros e peões (DeVries, 2007: 150). Anos depois, James F. Powers (2010, p. 490) estimaria a dimensão do exército cruzado nuns fantasiosos 100000 combatentes.

As propostas mais consistentes - e que, como tal, seguiremos surgiram através de Carlos Vara Thorbeck, que em 1999, na sequência de um rigoroso estudo sobre as características do local (a Mesa del Rey) onde a hoste cristã instalou o seu acampamento depois de atravessar a Sierra Morena, concluiu que a hoste dos cruzados não poderia ter uma dimensão superior a 4000 cavaleiros e 8000 peões (Thorbeck, 1999: 347-354). Trata-se de uma estimativa confirmada, um ano depois, por Martín Alvira Cabrer (2000: 192), que sugeriu um total entre os 10000 e os 14000 homens, opção que reiterou num estudo mais recente (Alvira, 2012: 330). Estas cifras foram aceites, entre outros, por Francisco García Fitz, no estudo monográfico que dedicou a Las Navas (2005/2008: 481, 488-489).

E se a hoste cristã era, a vários níveis, caracterizada por uma enorme heterogeneidade, o exército mobilizado por al-Nasir em 1212 era-o ainda mais. Com efeito, apresentava um núcleo central constituído pelos chamados "Almóadas de primeira hora", isto é, pelos contingentes da confederação de 
tribos berberes do Magrebe que, desde cedo, reconheceram a autoridade de Ibn-Tumart (o fundador, em 1120, do movimento almóada). Este núcleo integrava tropas montadas (nomeadamente algumas lanças de cavalaria pesada) e peões, talvez em número bastante expressivo e de entre os quais se destacavam os arqueiros apeados (García Fitz, 2008: 302-312 e 335) que, segundo o Rawd al-Qirtas (p. 468), totalizavam 10000 homens, um número claramente inflacionado.

A estas forças acrescentavam-se as que eram fornecidas pelas tribos berberes que só mais tardiamente haviam reconhecido a autoridade almóada, mas também as que foram incorporadas no império - nomeadamente por conquista - e que talvez constituíssem até um contributo numericamente superior ao dos "Almóadas de primeira hora", dos quais pouco se diferenciavam, exceto pelo facto de não incluírem, ao que parece, forças de cavalaria pesada (García Fitz, 2008: 312-317).

Igualmente importante, não só pelo seu papel tático como pelo número de combatentes envolvidos - que pode ter atingido entre $20 \%$ a $50 \%$ do total dos efetivos do exército califal reunido em 1212 - , foi o contributo das tribos árabes provenientes das regiões mais orientais do Norte de África. Tratava-se, sobretudo, de contingentes de nómadas cuja principal atividade tinha sido, desde sempre, a guerra e o roubo, e cuja integração teve como objetivo conferir uma maior agressividade aos exércitos califais e, ao mesmo tempo, retirar dessas zonas recém-conquistadas um dos principais agentes da resistência ao poder almóada. Ainda que pudessem incluir outro tipo de combatentes, estes "Almóadas tardios" — como são também designados —, contribuíam para a hoste sobretudo com efetivos de cavalaria ligeira.

Tal como os árabes, também os turcos (ou curdos) começaram a integrar os exércitos almóadas a partir do momento em que o império se expandiu para o leste do Norte de África, designadamente quando, depois de 1187, alcançou a Ifríquia, onde estavam instalados. Tratava-se, essencialmente, de forças de cavalaria ligeira, designadamente arqueiros a cavalo - munidos do célebre arco curvo — , que desde cedo se afirmaram como um dos principais corpos de elite das hostes almóadas (García Fitz, 2008: 320-334). 
Resultado da presença e expansão do império na Península Ibérica, o exército califal foi também passando a integrar um número cada vez maior de forças andaluzas, sobretudo de lanças de cavalaria pesada - que em pouco se diferenciavam, aliás, das que formavam as hostes cristãs -, o que lhes conferia um papel de enorme importância tática. Mais difícil é perceber qual o peso das forças de infantaria peninsulares, mas parece seguro que fariam também parte destes contingentes (García Fitz, 2008: 336-346).

Particularmente significativa e amplamente sublinhada pelas fontes narrativas cristãs parece também ter sido a presença de escravos negros, nomeadamente os que integravam a chamada Guarda Negra, ou seja, a guarda pessoal de al-Nasir, cuja principal missão era, justamente, a de defender o califa, se necessário fosse com o sacrifício da própria vida. Ainda que as informações de que dispomos não sejam claras a esse respeito, tudo indica que se tratava de um número consideravelmente elevado de efetivos, porém muito longe dos 30000 sugeridos pelo cronista Ibn Abi Zar (p. 468).

Por fim, o exército de al-Nasir integrava também um número expressivo de voluntários que, oriundos sobretudo do Magrebe, tinham seguido o chamamento do califa para a Jihad e que o Rawd al-Qirtas eleva para uns exagerados 160000 homens (p. 464). Se bem que longe dessas cifras, é admissível, no entanto, que se tratasse de um elevado número de efetivos, constituído apenas - ao que parece — por combatentes de infantaria.

Perante os dados disponíveis, torna-se impossível determinar com exatidão a dimensão do exército almóada, por um lado porque as informações veiculadas pelas fontes são muito fragmentárias e, por outro, porque as cifras totais que apenas algumas apresentam são, todas elas, demasiado exageradas e dignas de muito pouco crédito. O arcebispo de Toledo, por exemplo, afiança que as forças comandadas por al-Nasir totalizavam 80000 cavaleiros e um número incontável de peões, num total estimado em mais de 200000 homens (Livro VIII, cap. IX, pp. 321-323). Mais fantasiosas ainda conseguem ser as estimativas propostas por Afonso VIII, que aponta para uns 185000 cavaleiros e um número não contabilizado de tropas de infantaria (p. 571). No entanto, é Ibn Abi Zar, do lado muçulmano, 
que mais eleva esse cômputo, ao sugerir que a hoste califal totalizaria 500000 homens (p. 468), mesmo assim apenas metade do milhão de guerreiros que, ainda na primeira metade da centúria de Duzentos, era aventado pelo cronista Alberico, monge do mosteiro cisterciense de Trois Fontaines (cit. por García Fitz, 2008: 483-484).

Apesar do exagero generalizado das fontes, os vários autores que se debruçaram sobre o tema são unânimes quanto ao facto de a hoste almóada apresentar uma dimensão largamente superior à dos Cruzados. Huici Miranda (2000: 271), por exemplo, sugeriu - moderando substancialmente as estimativas elaboradas pelos autores seus contemporâneos - que teria, no máximo, entre 100000 e 150000 combatentes. Bastante inferior é a proposta de Kelly DeVries (2007: 150), que num pequeno estudo dedicado à Batalha de Las Navas sugeriu que o exército mobilizado por al-Nasir teria uma dimensão que rondaria os 52000 homens, um número muito próximo dos 50000 propostos, anos antes, por Hernàndez Cardona (2002: 63), mas ainda assim muito aquém dos mais de 100000 aventados em 2010 por James F. Powers (2010, p. 490).

Mais recentemente, os estudiosos têm optado por uma posição mais conciliadora e moderada, considerando que, se bem que largamente superior, o exército almóada não teria mais do que o dobro do número de combatentes do adversário, ou seja, rondaria os 22000 a 30000 combatentes, entre peões e cavaleiros (García Fitz, 2008: 490-491; e Alvira Cabrer, 2012: 332).

\section{O terreno e os dispositivos táticos}

Com a instalação definitiva dos acampamentos dos Cruzados e dos Almóadas, os contendores tinham pela sua frente o terreno onde, finalmente, iriam travar a grande batalha.

Este local, que - depois de durante muitos séculos se pensar que se situava junto ao castelo de Las Navas de Tolosa — só em 1916 foi identificado com rigor por Ambrosio Huici Miranda, localizava-se cerca de 12 ou $13 \mathrm{~km}$ a norte daquela fortaleza, ou seja, no sopé da face meridional 
da Sierra Morena. Era delimitado pela Mesa del Rey (a norte) e pelo Cerro de los Olivares (a sul), numa extensão de $3,5 \mathrm{~km}$; e estava definido a nas148 cente pelo Ribeiro del Rey e, a poente, pelo Ribeiro de la Campana, entre os quais se contava uma distância de aproximadamente $3 \mathrm{~km}$. Tratava-se de uma zona pouco arborizada, ampla, relativamente desafogada e, de um modo geral, plana, embora marcada a sul pelas ondulações que caracterizavam o relevo da zona mais próxima do Cerro de los Olivares (Huici Miranda, 2000: 282-289).

Foi, pois, aí, no local atualmente designado como Llano de las Américas, que, pela alvorada do dia 16 de julho de 2012, os dois exércitos começaram a instalar as suas forças e a organizar os seus dispositivos táticos.

Tal como a respeito de muitos outros aspetos da batalha, não são muitas as informações de que dispomos acerca da forma como cristãos e muçulmanos se distribuíram inicialmente pelo campo de batalha. Existem, no entanto, algumas indicações que permitem, se bem que sem grandes certezas, reconstituir os dispositivos táticos usados por um e pelo outro exército.

Quanto às forças cristãs, que foram as primeiras a posicionar-se no terreno, formaram três grandes blocos, ou colunas, com os castelhanos ao centro e com os flancos - como se de duas alas se tratasse - ocupados, à esquerda, pelos aragoneses e, à direita, pelos navarros. Por sua vez, cada uma destas três azes - como são designadas nas fontes coevas - encontrava-se subdividida em três unidades táticas, dispostas paralelamente e em profundidade, ou seja, organizadas em vanguarda, corpo central e retaguarda.

Mas vejamos mais detalhadamente - tanto quanto as fontes assim o permitirem - cada um desses três grandes blocos, começando a nossa observação pelo flanco esquerdo do exército cruzado, ou seja, pelas forças comandadas por Pedro II de Aragão.

A unidade mais adiantada de todas - a vanguarda - era liderada pelo experiente Garcia Romeu e integrava, sobretudo, forças de cavalaria pesada, mas também um número expressivo de peões. Um pouco mais atrás - as fontes não nos dizem a que distância, mas seguramente a algumas dezenas de metros - encontrava-se o corpo central, dividido por 
sua vez em duas unidades dispostas lado a lado e lideradas, da esquerda para a direita, por Aznar Pardo e Jimeno Coronel. A comandar a terceira e última linha, a retaguarda, encontrava-se o rei Pedro II, com o seu alferes 149 Ponço d’Erill, que empunhava o estandarte régio, acompanhados pelos efetivos mobilizados pelos bispos de Barcelona, de Berenguel e de Tarazona e por algumas das figuras de maior relevo da nobreza de Aragão, como o conde de Urgel, e os condes D. Sancho, Nuno Sanches e Pedro Aires. Para engrossar a retaguarda aragonesa foram ainda destacados alguns dos contingentes de cavalaria e de infantaria fornecidos pelas milícias concelhias castelhanas, provavelmente os três conrois que a rainha D. Berenguela afirma terem sido disponibilizados por seu pai, Afonso VIII (carta à irmã Branca, p. 573).

Imediatamente à direita dos aragoneses encontrava-se o bloco constituído pelas forças castelhanas — o mais numeroso dos três —, cuja vanguarda era comandada pelo veterano Diego Lopez de Haro, senhor de Biscaia, acompanhado pelo seu alferes Pedro Aires, pelo filho Lope Diaz e pelo sobrinho Sancho Fernandez (filho de Urraca e do rei Fernando II de Leão), com os respetivos vassalos e as suas mesnadas. Nesta unidade incluíam-se ainda os contingentes de voluntários leoneses e portugueses, entre peões e cavaleiros, e boa parte - senão mesmo a totalidade - dos Cruzados ultramontanos que tinham optado por permanecer na campanha, junto dos quais se encontraria o arcebispo de Narbonne, Arnau Amalric (Carta de Branca, p. 338). Com estas forças alinhavam também alguns contingentes de cavaleiros e de peões fornecidos, entre outras, pelas milícias concelhias de Madrid (Crónica de Veinte Reyes, cap. XXXII, p. 284). A carta de Branca de Castela sublinha precisamente esta enorme heterogeneidade da vanguarda castelhana, registando que se tratava de combatentes "recrutados aqui e ali”, num total que rondava as 300 (p. 338) a 500 lanças de cavalaria pesada (Crónica de Veinte Reyes, cap. XXXII, p. 284), cifras que nos parecem bastante verosímeis. Mais atrás, também a linha central castelhana - a mais numerosa das três e que integrava forças montadas e apeadas - estava dividida em duas subunidades: a da esquerda era liderada por Gonzalo Nunez de Lara e enquadrava, para além de diversas mesnadas senhoriais, 
os contingentes das Ordens Militares do Templo, de Calatrava, do Hospital e de Santiago, dirigidos, respetivamente, pelo português Gomes Ramires, 150 por Rodrigo (ou Rui) Dias, por Gutierre Hermenegildo e por Pedro Aires; enquanto a da direita era formada pelas mesnadas de Rui Dias de los Cameros - que a comandava —, do seu irmão Álvaro Dias e de Juan Gonzalez, com os seus vassalos. As fontes sugerem também a inclusão, nas fileiras destas duas unidades do centro castelhano, de diversas milícias concelhias (Rodrigo Jiménez de Rada, Livro VIII, cap. IX, p. 320), nomeadamente as de Cuenca, Huete e Alarcón, na da esquerda; e as de Soria, Almança, Atienza, San Esteban de Gormas e Ayllón, na da direita (Crónica de Veinte Reyes, cap. XXXII, p. 284). Por fim, capitaneada por Afonso VIII - acompanhado pelo alferes-mor Álvaro Nunez de Lara, que conduzia o pendão régio encontrava-se a retaguarda. Esta unidade era composta pelas mesnadas dos principais prelados e nobres castelhanos, entre os quais o arcebispo de Toledo e os bispos de Palencia, de Siguenza, de Osma, de Ávila, de Plasencia, de Burgos e de Calahorra (Alvira Cabrer, 2012: 235) - que a infanta Branca de Castela (p. 338) afirma, talvez erradamente, estarem nas linhas do centro castelhano - , e pelas mesnadas dos nobres Gonzalo Ruiz Girón, Rodrigo Perez de Villalobos, Suero Tellez e Fernán Garcia, entre outros. Para além destas forças, a retaguarda castelhana encontrava-se também engrossada pela presença de vários contingentes concelhios (Rodrigo Jiménez de Rada, Livro VIII, cap. IX, p. 320), tais como os de Toledo, Valladolid e Medina del Campo, que decerto contribuíram com um número significativo de cavaleiros e de peões (Crónica de Veinte Reyes, cap. XXXII, p. 284).

Por fim, à direita dos castelhanos, dispunham-se os navarros, designadamente os contingentes de D. Almoravid, de Pedro Martins de Leet e de Pedro Garcia de Premmis. Todavia, por contarem com forças numericamente mais reduzidas do que as dos seus aliados - recordemos que à chegada a Salvatierra foram contabilizadas apenas 200 lanças —-, foram substancialmente reforçados por alguns efetivos castelhanos de cavalaria e infantaria, designadamente pelos que foram mobilizados pelos concelhos de Segóvia, Ávila e Medina, tratando-se, muito provavelmente, dos outros três conrois mencionados por D. Berenguela, rainha de Leão, como tendo 
sido disponibilizados por Afonso VIII (p. 573). Estas forças encontravam-se distribuídas de forma em tudo semelhante à dos blocos castelhano e aragonês, ou seja, com uma vanguarda e um corpo central - sobre o qual as fontes nada adiantam, mas que parece não ter sido dividido em duas subunidades a que se acrescentava uma retaguarda, que sabemos apenas ter sido comandada pelo rei Sancho VII e onde se encontraria também o alferes Gomez Garcés de Agoncillo (Crónica de Veinte Reyes, cap. XXXII, p. 284).

Quanto ao dispositivo tático do exército almóada, obedeceu a um modelo bastante diferente daquele que havia sido adotado pelos Cruzados, mas acerca do qual as fontes muçulmanas são praticamente silenciosas e, por vezes, algo confusas. São, portanto, os relatos dos cristãos - ainda que igualmente parcos em informações e nem por isso menos confusos - os que mais úteis se revelam para a reconstituição da forma como as forças de al-Nasir se distribuíram no campo de batalha.

As unidades mais recuadas do exército estavam instaladas no topo de uma colina, talvez no Cerro de los Olivares, no célebre "curral" ou "palanque do Miramolim", como é quase sempre referido nas fontes cristãs. Tratava-se de uma solução tática de natureza defensiva, que consistia numa zona delimitada e protegida por um palanque, ou trincheira, improvisada com bagagens, caixas e cestos de munições, carros, pedras e estacas de madeira, no centro da qual sobressaía a tenda de couro vermelho do califa (Ibn-AbiZar, pp. 464-465), um dos principais símbolos da sua soberania e autoridade. Era aí que se encontrava al-Nasir, o seu séquito, os seus familiares e alguns altos dignitários almóadas, o que convertia essa zona num autêntico posto de comando, a partir de onde era possível observar o campo de batalha em toda a sua extensão e, assim, acompanhar e dirigir de forma mais eficaz os movimentos das tropas no terreno. Para além disso, o palanque servia também, como sublinha Martín Alvira (2012: 250), para garantir proteção à retaguarda do exército e, ao mesmo tempo, como ponto de referência, de concentração e de refúgio para os ginetes de cavalaria ligeira que, nas suas manobras rápidas, necessitavam constantemente de um local para reagrupar. Por tudo isso, a defesa do "curral" — tanto no seu exterior, quanto no interior 
- estava atribuída a diversas unidades de elite, nomeadamente à célebre "Guarda Negra", encarregada da guarda pessoal de al-Nasir e constituída, 152 sobretudo, por arqueiros, besteiros e fundibulários, mas também por um grande número de lanceiros que, com o conto das suas armas bem fincado no solo e com as lâminas apontadas para o exterior, garantiam a inexpugnabilidade do palanque. E para garantir que por nada abandonariam o seu posto, todos os combatentes apeados tinham as pernas atadas uns aos outros, o que os obrigava não só a permanecer no local, como a lutar até à morte pela sua defesa! Para além disso, tudo indica que no interior desse perímetro defensivo se encontrava também um número significativo de combatentes de cavalaria, como se infere do depoimento do arcebispo de Toledo e do texto da Crónica de Veinte Reyes (Rodrigo Jiménez de Rada, Livro VIII, cap. IX, p. 321; e Crónica de Veinte Reyes, cap. XXXIII, p. 285).

Encosta abaixo, imediatamente à frente do curral foi posicionada uma boa parte das forças de cavalaria pesada, almóada e andaluza (Alvira Cabrer, 2012: 252-253), protegidas nos flancos por forças de infantaria armadas de lanças e azagaias - que assim constituíam a retaguarda do dispositivo tático do exército muçulmano. Era também neste setor, onde sobressaía um elevado número de estandartes e bandeiras, que se encontravam dezenas de tocadores de tambor - mencionados tanto pelas fontes muçulmanas quanto pelas cristãs - que, através de sinais previamente estabelecidos, enviavam instruções e ordens para a frente de batalha, e cujo ruído ensurdecedor - que visava também aterrorizar o inimigo - tanto impressionou o arcebispo de Narbonne (p. 331).

Ainda que as fontes se mostrem bastante confusas a este respeito - já que só o relato do arcebispo de Toledo o menciona, e de forma muito vaga - , parece certo que, alguns metros à frente da retaguarda, se encontraria o corpo central da hoste de al-Nasir, o "pivot" de todo este dispositivo tático, como lhe chama García Fitz (2008: 50). Formada por um grande número de efetivos almóadas, árabes e andaluzes, era a maior das unidades do exército muçulmano, cabendo-lhe, por isso, a missão de absorver o impacto da carga inimiga. Tratava-se de uma formação que integrava, talvez combinadas numa disposição em quadrado, como era 
habitual nos exércitos do período almóada, forças de cavalaria pesada ao centro, protegidas no exterior por combatentes de infantaria, isto é, por lanceiros, adargueiros, lançadores de dardos, arqueiros e besteiros, encarregados de manter o inimigo à distância. Contudo, as fontes não permitem perceber ao certo quantos homens os integravam, nem sequer quantos seriam esses quadrados.

Seguiam-se, já no sopé da colina do Cerro de los Olivares, os voluntários da Jihad, ou seja, os combatentes, sobretudo de infantaria, que por sua livre e espontânea vontade haviam acorrido ao chamamento do califa para a Guerra Santa e que constituíam, assim, a vanguarda do exército muçulmano. Seria certamente um contingente muito numeroso, mas seguramente não tanto quanto os exagerados 160000 homens contabilizados por Ibn Abi Zar (p. 465). Pela sua localização, caber-lhes-ia a difícil missão de criar um primeiro obstáculo à progressão da carga inimiga, de modo a que esta pudesse ser mais facilmente travada e absorvida pelo corpo central da hoste.

No prolongamento de cada uma das extremidades da linha da frente, talvez até ligeiramente recuadas, encontrar-se-iam duas alas: uma no flanco esquerdo e outra no flanco direito, como parecem sugerir os testemunhos de Jiménez de Rada e de Arnau Amalric (Rodrigo Jiménez de Rada, Livro VIII, cap. IX, pp. 320-321; e Carta de Arnau Amalric, p. 331). Eram compostas por contingentes de cavalaria ligeira, na sua maioria árabes, mas também por arqueiros a cavalo, turcos e curdos - apoiados por alguns combatentes de infantaria, sobretudo besteiros e arqueiros - a quem estaria atribuída, por exemplo, a função de flanquear ou de atacar, caso fosse possível, a retaguarda das forças inimigas. Porém, ao que nos é dado perceber, nos momentos que antecederam a batalha uma boa parte destes efetivos foi enviada - com alguns atiradores de infantaria — para uma posição situada imediatamente à frente da vanguarda, a partir de onde deveriam fustigar as linhas avançadas do dispositivo tático cristão.

E assim, com ambos os exércitos dispostos no terreno, restava saber qual dos comandantes iria tomar a iniciativa de atacar, um passo que podia ser decisivo e que, como todos o sabiam, poderia ditar o curso e o desfecho da grande batalha de 16 de julho de 1212 . 


\section{A batalha}

As primeiras movimentações tiveram início, talvez, perto das oito horas da manhã, com as ações ofensivas levadas a cabo pela cavalaria ligeira almóada, bem como pelos arqueiros montados turcos e curdos que integravam a hoste califal (Alvira Cabrer, 2012: 275). O arcebispo de Toledo dá-nos uma preciosa descrição destas manobras: "dedicados a desconcertantes cavalgadas, não mantêm a formação com o objetivo de desbaratar os contrários com as suas descobertas e de abrir caminho aos seus, que marcham em formação, uma vez desordenadas as linhas do opositor" (Livro VIII, cap. IX, p. 321). Esta é, aliás, uma imagem reiterada por outra testemunha presencial, o arcebispo de Narbonne, Arnau Amalric, que não deixou de sublinhar, até com algum espanto, que estes combatentes "lutam correndo sem ordem fora das fileiras" (p. 331). Trata-se do célebre torna-fuy, isto é, de manobras de "ataque e retirada" — ou de fuga simulada - protagonizadas pelos ginetes muçulmanos e que, em conjugação com os arqueiros montados, tinham por objetivo causar baixas e abrir brechas nas linhas inimigas, deixando-as fragilizadas, desorganizadas e, assim, à mercê de um ataque frontal. Estas eram ações que serviam também para provocar o adversário, levando-o a lançar a carga de forma precipitada e sem as condições essenciais para o sucesso. Contudo, ao contrário do que tinha sucedido em Alarcos, em 1195 - quando a cavalaria de Afonso VIII se lançou prematuramente na perseguição (Monteiro, 2011: 24) - desta feita os cavaleiros cristãos, provavelmente melhor controlados pela sua estrutura de comando, não se deixaram cair na armadilha, aguardando pacientemente pelo momento indicado para a investida (García Fitz, 2008: 531).

Com efeito, já perto das 9 horas da manhã (Alvira Cabrer, 2012: 275), as ações de desgaste protagonizadas pelos ginetes muçulmanos abrandaram ou terão mesmo cessado. A cavalaria cristã tinha por fim um alvo estável à sua frente, contra o qual podia arremeter. A ofensiva coube às vanguardas castelhana e aragonesa, comandadas, respetivamente, por Diego Lopez de Haro e Garcia Romeu, e, muito provavelmente, embora as fontes não o refiram, também às linhas da frente do contingente navarro (García Fitz, 
2008: 526). O terreno que tinham que percorrer apresentava-se, no entanto, irregular, pedregoso e - como sublinha Afonso VIII na carta enviada ao papa Inocêncio III (p. 370) —, marcado pela presença de algum arvoredo, ou seja, longe de ser o ambiente ideal para o lançamento de uma carga frontal. Mesmo assim, a progressão da cavalaria, seguida de perto pela peonagem, fez-se de forma ordenada e coesa, primeiro a passo e depois num trote rápido ou a galope, na direção dos ginetes muçulmanos, que rapidamente recuam - sem que se perceba se a retirada constituiu uma ação premeditada, à maneira de torna-fuy, ou se, pelo contrário, se tratou de uma fuga real, como parecem sugerir algumas fontes - uns para junto do corpo central da hoste califal, outros para as alas (Carta de Arnau Amalric, p. 331).

Afastado esse primeiro obstáculo, a carga prossegue ao encontro da vanguarda inimiga, integrada pelos voluntários da Jihad e posicionada por detrás de um pequeno vale, uma zona do campo de batalha que certamente foi escolhida pelo comando almóada para conferir alguma proteção a esses efetivos e, ao mesmo tempo, para tentar quebrar o ímpeto e a organização da carga adversária.

Ainda assim, o choque entre as duas formações deve ter dado imediatamente vantagem aos atacantes, que - a fazer fé no testemunho das fontes - desbarataram sem dificuldade de maior as forças inimigas. Embora alguns combatentes tenham conseguido retirar e integrar-se nas unidades do corpo central e da retaguarda da hoste califal (Carta de Arnau Amalric, p. 331), a maioria terá sido atropelada e esmagada pela cavalaria cristã logo nos momentos iniciais do choque. O cronista Ibn Abi Zar não deixa de manifestar alguma surpresa pela forma como esses mártires "desapareceram" entre as fileiras dos cristãos (p. 465), uma afirmação que parece confirmar a escassa resistência que ofereceram. De facto, a grande motivação religiosa destes voluntários não chegava, como sublinhou García Fitz (2008: 355), para substituir ou sequer para compensar a sua reduzida preparação para a batalha. Ultrapassado mais este obstáculo, a carga prossegue em direção ao corpo central da hoste de al-Nasir, posicionado algumas dezenas de metros à sua frente, a meio da colina do Cerro de los Olivares. 
A partir dessa fase da batalha, a progressão das forças cristãs fez-se de forma mais lenta do que seria desejável, pois os atacantes, provavelmente já algo desorganizados em resultado do choque com os voluntários da Jihad, tiveram ainda que percorrer um terreno irregular e inclinado, colina acima, o que fez com que perdessem - alguns terão mesmo parado (Primera Crónica General, cap. 1019, p. 701) —, mais algum do seu ímpeto e organização. Consequentemente, o efeito produzido sobre as compactas formações em quadrado do centro da hoste almóada terá ficado muito aquém do desejado, já que o adversário não só absorveu com sucesso a carga, como começou de imediato a ripostar e a contra-atacar.

Ainda assim, é possível que algumas das forças da vanguarda castelhana, nomeadamente as que seguiam mais próximas de Diego Lopez de Haro, tenham conseguido romper aquela autêntica muralha humana. Terá sido, no entanto, um grupo relativamente reduzido de combatentes a fazê-lo, ficando de imediato isolados e perigosamente entalados, no meio de uma densa nuvem de poeira, entre as últimas linhas das unidades do centro e as primeiras da retaguarda almóada (Crónica de Veinte Reyes, cap. XXXIIII, p. 285). No entanto, decerto que a muito custo, terão conseguido — através da brecha que tinham acabado de abrir — fazer meia-volta e retroceder para junto dos camaradas de armas que lutavam na mêlée.

Face aos escassos resultados obtidos pela primeira carga, o comando das forças cristãs decide de imediato lançar uma segunda investida, desta feita conduzida pelas unidades centrais castelhana - liderada, muito provavelmente, por Gonzalo Nuñez de Lara - e aragonesa. Contudo, tal como sucedera com a primeira, também esta carga parece ter-se desagregado, mais uma vez em resultado das asperezas do terreno e, por outro, em consequência do contacto com os destroços das unidades de voluntários da Jihad, o que levou a que em alguns sectores o choque com as linhas do centro almóada tenha sido, novamente, mais débil do que seria esperado (Alvira Cabrer, 2012: 276). Nesta fase da luta, em que o corpo-a-corpo tinha já substituído a organização tática inicial, as baixas cristãs começam a avolumar-se, nomeadamente entre os que se encontravam mais desprotegidos, isto é, entre as forças de infantaria, como nos dá conta 
o testemunho de Branca de Castela, que assinala a morte de 40 peões logo nos momentos que se seguiram ao contacto com o adversário (Carta a Branca de Champagne, p. 338).

Talvez tenha sido essa a altura em que as unidades do corpo central da hoste navarra - as quais, ao que parece, e sem que as fontes adiantem o motivo, não tinham acompanhado a segunda carga das forças castelhanas e aragonesas - avançaram contra o seu opositor direto, isto é, contra a ala esquerda inimiga, juntando-se, assim, aos seus companheiros da vanguarda envolvidos na luta desde os momentos iniciais da batalha. A manobra terá sido conduzida com algum sucesso, tendo mesmo forçado o inimigo a recuar. Enquanto isso, no outro extremo do campo de batalha, os contingentes aragoneses continuavam a pressionar a ala direita adversária, porém, sem grandes resultados práticos, tal como acontecia na zona central com os castelhanos. Nesta fase do prélio, era ainda impossível descortinar para que lado iria pender a sorte das armas, como se percebe pelos testemunhos do arcebispo Rodrigo Jiménez de Rada (Livro VIII, cap. X, p. 321) e, sobretudo, de Juan de Soria, que sintetiza de forma eloquente o que então se passava no campo de batalha: "insistem os cristãos, resistem os mouros" (p. 33).

Foi então que, ao som de inúmeros tambores, teve lugar um violento e bem-sucedido contra-ataque do centro almóada que, provavelmente reforçado por alguns dos contingentes da retaguarda, obrigou as forças cristãs a recuar, comprimindo ainda mais os guerreiros que tinham executado a primeira carga contra a segunda linha do exército cristão, a qual, como vimos, estava também já envolvida nos combates. Como um baralho de cartas, a frente de batalha começa a desmoronar-se e a desconjuntar-se em diversos sectores, tal era a pressão exercida pela hoste califal. As dificuldades avolumam-se a um ponto tal que Diego Lopez de Haro, que nessa altura já só tinha consigo 40 dos cavaleiros que o tinham acompanhado na arremetida inicial, dirigiu um apelo desesperado ao rei para que este lançasse as últimas forças na batalha (Crónica de Veinte Reyes, cap. XXXIIII, p. 285). Nesse momento, Afonso VIII terá pensado em fazer entrar em ação os efetivos de que ainda dispunha, ou seja, os contingentes das retaguardas castelhana, aragonesa e navarra, e em liderar pessoalmente 
uma derradeira carga, na qual estaria disposto a morrer. Contudo, foi travado in extremis pelo arcebispo de Toledo e, sobretudo, por Fernán Garcia, que 158 lhe terá aconselhado prudência e sugerido, em alternativa, que enviasse apenas algumas forças para reforçar as zonas onde a pressão almóada era mais acentuada e/ou onde os combatentes cristãos começavam a fraquejar.

Parece ter sido a intervenção desses contingentes retirados da retaguarda castelhana - possivelmente comandados pelo próprio rei, como regista a carta de Berenguela à sua irmã Branca (p. 373), ou por Gonçalo Ruiz Girón e seus irmãos, como sugere o testemunho de Rodrigo Jiménez de Rada (Livro VIII, cap. X, p. 322) - que conseguiu, por um lado, reagrupar algumas das forças que se encontravam já em debandada, convencidas de que a batalha estava perdida, e, por outro, recompor e consolidar as já muito fragilizadas linhas da frente de batalha, evitando assim o seu colapso. Ainda que as fontes não o refiram, é provável que esta manobra ofensiva tenha também envolvido alguns destacamentos provenientes da retaguarda aragonesa, que assim vieram reforçar os efetivos envolvidos na luta contra a ala direita inimiga, onde, como referimos, as dificuldades eram também inúmeras (Alvira Cabrer, 2012: 279-280).

Contudo, o rumo dos acontecimentos - muito provavelmente em resultado de um segundo contra-ataque almóada (Alvira Cabrer, 2012: 278) - parece ter obrigado a uma nova intervenção da retaguarda castelhana, de onde foram destacados mais alguns contingentes para recompor a frente de batalha. Porém, as fontes voltam a não ser suficientemente esclarecedoras a respeito desta manobra que, segundo o depoimento de D. Berenguela (p. 373), terá sido conduzida novamente sob o comando pessoal do rei.

Mas mesmo com estas medidas de contenção, a pressão almóada, sobretudo depois de o grosso das forças da sua retaguarda se envolver também nos combates, nunca abrandou, tendo-se mesmo intensificado. Entre os cristãos, sobretudo entre os que combatiam nas primeiras linhas, as baixas avolumavam-se e as formações começavam novamente a desfazer-se. Ato contínuo, um número considerável de cavaleiros e peões, muitos dos quais feridos, abandona a luta e começa a fugir, arrastando atrás de si, como ilustra a Crónica de Veinte Reyes, os seus estandartes e pendões (cap. XXXIIII, p. 285). O arcebispo Rodrigo Jiménez de Rada sublinha a 
circunstância de entre estes fugitivos não se encontrarem quaisquer nobres, dando a entender que teriam sido as milícias concelhias a iniciar a debandada (Livro VIII, cap. X, p. 321), uma perspetiva partilhada pelo arcebispo de Narbonne, que atribui aos "serranos" a responsabilidade da fuga (p. 332).

A debandada desses homens terá levado a que muitos outros pensassem que a batalha estava irremediavelmente perdida e acabassem por seguir o exemplo dos seus companheiros de armas, conforme sintetiza Arnau Amalric, ao afirmar que "quase todo o exército (...) parecia fugir" (p. 331). Por outro lado, a visão do inimigo em debandada terá motivado ainda mais os Almóadas que, percebendo que a vitória poderia estar próxima, intensificaram a pressão e o vigor dos golpes desferidos pelas suas armas. Até mesmo as experimentadas lanças de cavalaria das Ordens Militares — que inicialmente integravam, como vimos, o corpo central da hoste castelhana - começam também a sentir grandes dificuldades para suportar a pressão adversária. De facto, tanto a morte dos mestres do Templo e de Santiago, na sequência dos ferimentos sofridos na batalha, quanto as lesões sofridas pelo mestre de Calatrava parecem confirmar a dureza dos combates neste sector da mêlée.

E não era apenas no centro que os problemas se avolumavam, já que nas alas a situação não era melhor. É mesmo possível que os muçulmanos se tivessem apercebido do enfraquecimento dos flancos inimigos e explorado a possibilidade de os pressionar ainda mais e, assim, levar a cabo uma manobra de envolvimento da hoste cristã, ou até um ataque à retaguarda (Alvira Cabrer, 2012: 277). Ou seja, em qualquer dos setores do campo de batalha, os Cruzados começavam a soçobrar, não só pelo poderio da imparável investida inimiga como pela fadiga resultante de mais de duas horas de intensos combates.

Foi então, já perto do meio-dia (Carta de Berenguela, p. 373), que Afonso VIII ordenou o avanço definitivo das retaguardas castelhana, aragonesa e navarra, um movimento que Branca de Castela (p. 338) refere ter sido conduzido em simultâneo — "um só ataque" — por essas três unidades táticas, como aliás dá também a entender o arcebispo de Narbonne (p. 332). Era o tudo-por-tudo do exército cruzado!

A maior parte das fontes interpreta esta decisão, por um lado, como um ato de desespero do rei castelhano perante a rotura da frente de batalha 
e, por outro, como uma decisão que, face à insistência de Afonso VIII, era impossível - segundo Juan de Soria e o arcebispo de Toledo - continuar 160 a adiar por mais tempo, sobretudo a partir do momento em que se tornou mais do que evidente que os cristãos estavam à beira de um desaire em tudo semelhante ao de Alarcos. Parece-nos, contudo, que, ao contrário do que é sugerido pelos depoimentos daqueles cronistas, o lançamento desta derradeira carga resultou não de um impulso desesperado do rei castelhano, mas sim de uma leitura muito atenta e lúcida da evolução dos acontecimentos.

Com efeito, é muito provável que o comando da hoste dos Cruzados - não necessariamente Afonso VIII, mas os combatentes e líderes mais experientes que o acompanhavam - tenha deliberadamente aguentado a frente de batalha até ao último momento, recorrendo para isso apenas ao contributo das forças da vanguarda e do corpo central do exército, reforçadas pontualmente por alguns destacamentos provenientes das unidades mais recuadas. Claro que isso provocou um enorme desgaste físico e emocional naqueles efetivos, porquanto foram obrigados a resistir praticamente sem o apoio da retaguarda. Mas essa era a única forma que os cristãos tinham de obrigar al-Nasir a enviar praticamente todos os seus homens para a frente de batalha e, simultaneamente, manterem intacta uma importante e numerosa reserva tática que pudesse ser lançada para a ação apenas no momento em que era humanamente impossível continuar a suportar por mais tempo a pressão dos Almóadas.

A ofensiva das três retaguardas - marcada pelo avanço de inúmeros estandartes e pendões, designadamente os de Afonso VIII, de Pedro II e de Sancho VII - foi absolutamente esmagadora, em boa medida porque o inimigo, que decerto não contaria já com esta cartada, foi apanhado completamente desprevenido. A hoste muçulmana estaria de tal forma convencida da vitória que em alguns sectores tinha já desfeito as suas formações para se lançar na perseguição dos inimigos em fuga. Foi, pois, sem grande oposição que a "carga dos estandartes", como lhe chama Martín Alvira (2012: 285), conseguiu entrar pelas linhas adversárias adentro, provocando desde logo a debandada de muitos muçulmanos. O vigor do choque foi tal que alguns dos contingentes de cavalaria pesada envolvidos na manobra conseguiram 
mesmo rasgar por completo essas linhas, atingindo, na sequência desse movimento ofensivo, as imediações do "palanque do Miramolim".

Ao aperceber-se da aproximação da cavalaria cristã, do colapso das unidades do centro, bem como de algumas outras da retaguarda, mas, acima de tudo, de que o seu posto de comando estava prestes a ser atacado, o califa e o respetivo séquito põem-se em fuga. As fontes discordam quanto a esta súbita retirada de al-Nasir, que segundo algumas narrativas terá sido escoltado por um forte contingente da sua guarda pessoal, mas que de acordo com a maior parte dos relatos produzidos pelos vencedores - talvez preocupados em sublinhar o carácter desonroso e precipitado da debandada - terá contado apenas com o apoio de um pequeno grupo de cavaleiros. Quaisquer que tenham sido as forças que o acompanharam, não restam dúvidas de que a notícia da sua fuga terá contribuído ainda mais para espalhar o pânico e a confusão no seio dos combatentes almóadas, que assim percebiam que a batalha estava irremediavelmente perdida. Nada mais lhes restava a não ser porem-se também a salvo o quanto antes.

A perseguição aos fugitivos, muitos dos quais retiravam na direção do palanque do califa, onde decerto esperavam encontrar alguma proteção, levou os castelhanos, seguidos por aragoneses e navarros, até às imediações desse último reduto adversário, onde a luta se reacendeu. No entanto, as forças comandadas por Afonso VIII — provavelmente as primeiras a chegar junto do "curral" - foram incapazes de ultrapassar de imediato a muralha humana constituída pelas unidades de elite da Guarda Negra, que, sem forma de escapar - recorde-se que estes guerreiros estavam atados uns aos outros para prevenirem uma eventual fuga - , terão oferecido feroz resistência aos combatentes inimigos. Sobre esta fase da batalha, a que as fontes mais próximas dos acontecimentos, curiosamente, não dão qualquer destaque, os relatos divergem, por vezes assumindo tonalidades algo fantasiosas, como no caso da Crónica de Veinte Reyes (cap. XXXIIII, p. 286), onde se realça o papel desempenhado pelo alferes castelhano Álvaro Nuñez de Lara - um dos primeiros a chegar ao local —, que terá saltado com o seu cavalo sobre os inimigos e sobre as defesas do palanque, dando assim início à conquista do último reduto inimigo. Mais verosímil, apesar de bastante 
mais tardio, é o relato de Ibn Abi Zar (p. 466), segundo o qual a muralha humana constituída pela guarda pessoal do califa e pelas inúmeras estacas 162 e lanças cravadas no solo só foi quebrada porque os cristãos forçaram de tal forma os seus cavalos - designadamente os que envergavam lorigas de malha de ferro - contra esses combatentes que acabaram mesmo por romper aquele perímetro defensivo. Impossibilitados de fugir, os membros da guarda pessoal do califa acabaram chacinados nesse mesmo local onde, pouco depois das forças de Afonso VIII, chegavam também os contingentes liderados pelos reis de Aragão e de Navarra. Com a conquista do "palanque", confirmava-se o que tinha já tinha sido anunciado pela fuga de al-Nasir: a batalha estava decidida a favor dos Cruzados.

Sem ter uma noção exata da dimensão do desastre que acabara de ocorrer, o califa percorreu rapidamente os cerca de $40 \mathrm{~km}$ que separavam o campo de batalha da praça-forte de Baeza. Ao aperceber-se da sua chegada e do desfecho da batalha, os habitantes ter-lhe-ão perguntado, de acordo com o relato de Rodrigo Jiménez de Rada (Livro VIII, cap. X, p. 322), o que podiam fazer, ao que o desnorteado, confuso e profundamente abatido al-Nasir terá respondido apenas: "Não posso velar nem por mim, nem por vós; ficai com Deus”. Após uma rápida troca de montada, terá imediatamente partido em direção à cidade de Jaén, onde também não se demorou, dirigindo-se logo para Sevilha.

À debandada dos sobreviventes - fatigados, feridos, desorientados e, nas palavras de Juan de Soria, "como ovelhas sem pastor" (p. 33) seguiu-se uma autêntica “caça ao homem”, que terá envolvido um grande número de combatentes cruzados, entre os quais o próprio Afonso VIII, bem como os monarcas aragonês e navarro. A perseguição e a chacina de todos os que por eles eram alcançados ter-se-á arrastado por várias horas, ou seja, por muitos quilómetros; mais de uma centena, segundo os Annales da abadia de Saint Pierre de Jumièges — fonte que regista também a notícia do massacre de várias mulheres encontradas pelo caminho (cit. por Alvira Cabrer, 2012: 291-292) _, ou, numa estimativa mais modesta e realista, até Vilches, povoação situada a $25 \mathrm{~km}$ de distância (Crónica de Veinte Reyes, 
cap. XXXV, p. 286), o que se compagina tanto com o relato de Afonso VIII, quanto com a missiva de Berenguela de Leão enviada a sua irmã Branca de Castela (Carta de Afonso VIII, p. 571; e Carta de Berenguela, p. 573).

Segundo o arcebispo Arnau Amalric (p. 332), nas horas que se seguiram à batalha foram mortos tantos mouros quantos os que haviam perecido em combate, uma informação que vem, de certa forma, ao encontro do que é afirmado pelo Rwad al-Qirtas (p. 467) - a única fonte que alude a esse facto - , segundo o qual os líderes cruzados terão dado instruções aos seus homens para que não fizessem quaisquer prisioneiros durante a perseguição, provavelmente devido aos problemas logísticos que isso iria acarretar, sobretudo ao nível da distribuição de mantimentos.

Se bem que algumas forças só tivessem regressado na manhã seguinte, esta autêntica caçada teve o seu epílogo ao anoitecer, como refere a Cronica Latina de los Reyes de Castilla, quando os combatentes cristãos se sentiram saciados com a efusão de sangue dos mouros, ou mais provavelmente quando, devido à escuridão noturna, se tornou demasiado arriscado continuar a perseguição (Juan de Soria, p. 33). Tinham decorrido aproximadamente 12 horas desde o início da batalha...

\section{O rescaldo da batalha e o final da campanha}

Com os três reis e a maior parte dos combatentes de novo reunidos, tiveram então lugar as inevitáveis missas e celebrações litúrgicas em ação de graças pelo triunfo conseguido horas antes, entre as quais um solene Te Deum oficiado pelos bispos de Palencia, Siguenza, Osma, Plasencia e Ávila, entre muitos outros religiosos.

Instalados agora no acampamento inimigo - para onde transferiram tudo o que, horas antes, havia sido deixado no arraial da Mesa del Rey -, os Cruzados permaneceram durante o dia seguinte (17 de julho) junto do campo de batalha, um ato carregado de simbolismo e que tinha, como era da praxe, o propósito de sublinhar e confirmar a vitória. Porém, a presença nesse local serviu igualmente objetivos muito práticos, tais como o de 
permitir uma melhor divisão e distribuição do espólio deixado no terreno pelo inimigo, uma tarefa complexa e de enorme responsabilidade, de que 164 foi encarregado Diego Lopez de Haro, um dos heróis da jornada. Aí foram encontradas incontáveis riquezas: ouro, prata, roupas de luxo, arreios de seda e outros ornamentos valiosíssimos, para além de inúmeros animais, entre os quais muitos dromedários e um elevado número de cavalos. A ocupação do acampamento inimigo possibilitou também aos vencedores apropriarem-se de grandes quantidades de mantimentos abandonados pelos Almóadas, fundamentais para suprir os graves problemas de abastecimento sentidos nas semanas anteriores.

Mas a permanência dos vencedores nas proximidades do campo de batalha servia ainda um outro propósito, o de identificar, recolher e - em alguns casos - sepultar os cadáveres dos cristãos tombados em combate (Alvira Cabrer, 2012: 297-298 e 302). Terá sido então, enquanto tinha lugar essa macabra contabilidade, que foi possível perceber um pouco melhor a dimensão da vitória.

As cifras veiculadas a esse respeito pelas fontes são, como é habitual, muito exageradas - quer do lado dos vencedores, quer do lado dos vencidos -, procurando com isso, ora ampliar a dimensão do triunfo, ora escamotear o peso da derrota, pelo que os números que difundem têm sido sistematicamente postos em causa pelos estudiosos da batalha.

Com as fontes muçulmanas a remeter-se, compreensivelmente, ao silêncio sobre o número total de baixas, são os testemunhos dos cristãos os únicos que se debruçam sobre o tema, avançando com estimativas que oscilam entre os 200000 mortos do lado dos derrotados propostos por Jiménez de Rada e os 60000 referidos na carta de Arnau Amalric (Rodrigo Jiménez de Rada, Livro VIII, cap. X. p. 323; e Carta de Arnau Amalric, p. 332), passando pelos 100000 adiantados por Afonso VIII (p. 571) e pelos 85000 (15 000 dos quais mulheres) aventados por Berenguela (p. 573).

Quanto às baixas sofridas pelos cristãos, os relatos produzidos do lado dos vencedores conseguem ser ainda mais exagerados, mas por defeito. As cartas de Afonso VIII e de suas filhas avançam com um total de mortos cristãos que varia, por um lado, entre os 300 combatentes de "escalão inferior" 
e os 200 propostos, respetivamente, por Branca de Castela (p. 338) e por Berenguela (p. 573) e, por outro, entre os escassos 20 ou 30 referidos na carta enviada pelo rei castelhano ao papa Inocêncio III (p. 571) e os 25 tombados em combate a que alude o arcebispo de Toledo (Livro VIII, cap. X. p. 323). Pelo meio, os cálculos variam, entre as 50 baixas apresentadas pelo arcebispo de Narbonne (p. 332) e as 150 registadas pela Crónica de Veinte Reyes (cap. XXXV, p. 286), ainda assim todas elas cifras muito aquém daquele que deve ter sido o número real de combatentes que, do lado dos Cruzados, sucumbiu no campo de batalha.

Perante estas estimativas — todas elas pouco fiáveis - é praticamente impossível avaliar o número de homens mortos em combate durante a batalha e nas horas que se seguiram, motivo pelo qual a maior parte dos estudos que se debruçam sobre Las Navas não apresenta cálculos relativos às baixas verificadas de um lado ou do outro. Parece, no entanto, evidente que o exército almóada terá sofrido um número muito mais avultado de perdas do que o dos Cruzados. Os motivos podem encontrar-se, por um lado, na perseguição que se seguiu à batalha, onde muitos terão perecido, mas também no facto de, como notou Martin Alvira (2012, pp. 336-338), os efetivos cristãos se encontrarem - em particular os seus cavaleiros muito melhor protegidos do que os Almóadas, envergando eficazes defesas de malha de ferro que os cobriam praticamente da cabeça até aos pés, o que terá limitado o número de mortos e de feridos.

Ainda assim, adotando uma ratio sugerida por Philippe Contamine e por Philip Morgan para as baixas sofridas pelos exércitos derrotados em enfrentamentos campais durante a Idade Média, é muito provável que os muçulmanos tenham perdido entre 20 e 50\% dos seus efetivos (Contamine, 1996: 257-258; e Morgan, 1987: 154), ou seja, um número que - em função dos 20000 a 30000 combatentes que integravam hoste de al-Nasir — pode perfeitamente ter correspondido a uma perda de 4500 a 15000 homens.

Mas qualquer que tenha sido o número de baixas - tanto de um lado, quanto do outro - , poucos seriam os que, entre os Cruzados, duvidavam do enorme sucesso alcançado no campo de Las Navas de Tolosa. Tratava-se, no entanto, de um êxito que, na perspetiva de Afonso VIII, havia que 
continuar a explorar, de forma a tirar o máximo partido do desnorte que o desfecho da batalha tinha produzido no seio do poder político e militar 166 almóada. E assim, no dia 18, logo pela manhã - apressado também pelo cheiro nauseabundo dos cadáveres deixados insepultos no campo de batalha (Huici Miranda, 2000: 273) —, o exército cruzado levanta o acampamento e avança para sul, em direção às margens do rio Guadiel, a partir de onde envia diversos destacamentos para procederem à ocupação dos castelos vizinhos de Vilches, Baños, Ferral e Tolosa, assegurando dessa forma o controlo das principais rotas de travessia da serra.

No dia 20, de novo com o exército todo reunido, o alvo foi a povoação de Baeza, que a hoste cristã encontrou praticamente deserta em virtude de os seus habitantes e da guarnição, ao saberem da aproximação das forças inimigas, se terem refugiado em úbeda — para onde fugiram também muitos dos sobreviventes de Las Navas; e isto porque Úbeda era uma cidade cujas estruturas de defesa ofereciam melhores garantias de poderem resistir a um cerco. A exceção era um grupo de velhos e de doentes que, por não poderem viajar, se haviam refugiado na mesquita de Baeza, mas onde acabaram queimados vivos, tudo o indica, de forma deliberada e por ação dos Cruzados.

Ainda que um número substancial de combatentes, entre os quais Afonso VIII, Pedro II e Sancho VII, tenha permanecido em Baeza, o grosso da hoste cristã avançou de imediato em direção a Úbeda, dando início às operações de cerco. No dia seguinte (sábado, 21 de julho), já com o exército novamente reagrupado, os Cruzados intensificam o assédio à praça-forte. Apesar de os sitiados terem oferecido forte resistência, ao fim de dois dias os sitiadores conseguiam, através de uma mina, derrubar uma das torres da muralha e tomar a cidade na sequência de um assalto massivo. Muitos muçulmanos ainda conseguiram refugiar-se no alcácer, mas acabaram por depor as armas ao cabo de algumas horas, depois de encetadas as conversações com os representantes de Afonso VIII com vista a uma rendição negociada.

Mas o acordo alcançado entre ambas as partes, que previa a partida pacífica dos Cruzados, abdicando de pilhar a cidade e abstendo-se de atos violentos contra a população, em troca da entrega de uma exorbitante quantia em dinheiro e riquezas, acabou por ser rejeitado pelo próprio rei que, 
subitamente e sem que nada o fizesse prever, mudou de opinião quanto ao destino a dar à cidade e seus habitantes. Os motivos para esta atitude não são fáceis de identificar, pois as fontes divergem a esse respeito. Assim, enquanto alguns relatos sugerem terem sido os arcebispos de Narbonne e de Toledo que obrigaram o rei a mudar de ideias, por acharem um tal acordo inaceitável, por ser demasiado brando, outras apontam o recuo de Afonso VIII como tendo sido resultante da pressão exercida por alguns setores da nobreza que, devido ao acordo alcançado, se viam privados da possibilidade de obtenção de um avultado botim; ao passo que outras ainda justificam aquela mudança de posição com o resultado dos desentendimentos entre os monarcas castelhano e aragonês a respeito do domínio da cidade e do respetivo saque (Alvira Cabrer, 2012: 355-358; e García Fitz, 2008: 177). Por isso mesmo, terá sido elaborado um novo acordo, mais penalizador para os muçulmanos e que os obrigava a abandonar a cidade e a entregá-la aos Cruzados, bem como uma avultada soma de dinheiro, como contrapartida pelo facto de verem as suas vidas poupadas (Carta de Arnau Amalric, p. 333).

Fosse como fosse - quem sabe até se por as gentes de Úbeda não terem sido capazes de reunir as somas estipuladas —, também este acordo foi posto de lado e a cidade acabou mesmo por ser pilhada, os seus muros foram destruídos e muitos dos seus habitantes foram chacinados ou feitos prisioneiros. Ao relatar ao papa a tomada de Úbeda, Afonso VIII fala em 60000 mortos (pp. 571-572), ao passo que os depoimentos de Juan de Soria (p. 35) e do cronista muçulmano Ibn Abi Zar (p. 467) dão um maior destaque aos 100000 homens, mulheres e crianças reduzidos ao cativeiro, embora todas aquelas cifras possam estar inflacionadas.

Empolgado pelos sucessos dos últimos dias, o monarca castelhano pretendia prosseguir a campanha e estendê-la pelo menos durante mais algumas semanas, para assim continuar a explorar os efeitos das vitórias obtidas em Las Navas e em Úbeda. No entanto, não era essa a vontade nem dos seus aliados aragoneses e navarros, nem sequer da maior parte dos combatentes castelhanos que, pressionados pela fadiga, pelo calor abrasador, pela fome - que não poupava sequer os animais - e, acima de tudo, pelos problemas de saúde que assolavam a hoste, preferiam regressar a casa o quanto antes. 
Como resume Francisco García Fitz, "aquele exército tinha permanecido no campo durante mais de um mês, tinha percorrido uns trezentos quilómetros durante cinco semanas sob o inclemente sol de verão de La Mancha e da Andaluzia, tinha participado na anexação e assalto de várias fortalezas e tinha sido submetido ao enorme stress de uma batalha campal de dimensões extraordinárias, tendo-o feito com meios logísticos pobres, bebendo pouca água e presumivelmente insalubre, alimentando-se de forma deficiente e vivendo em situações de extrema falta de higiene. Necessariamente, ao fim de pouco mais de um mês, os corpos tinham chegado ao extremo da sua resistência" (2008: 262-263). Estava na altura de pôr um ponto final a todas essas provações.

A campanha de 1212 terminava, assim, com a conquista de Úbeda, de onde as forças cristãs marchariam para Calatrava, onde se encontraram com o duque da Áustria, que havia chegado atrasado para a batalha e de onde as forças aragonesas, encabeçadas por Pedro II, partiram de regresso a casa. Daí, o exército cruzado, ainda com a presença dos contingentes navarros e, talvez, também dos ultramontanos, regressaria a Toledo, onde foi recebido triunfalmente pela população da cidade - a Crónica de Veinte Reyes (cap. XXXVI, p. 287) afirma que até mesmo os judeus e os mouros da cidade se juntaram às celebrações; a entrada ficou marcada por um ambiente festivo, onde não faltaram a música e as celebrações litúrgicas, que tiveram como ponto alto a procissão que percorreu as principais artérias da cidade e que culminou na Igreja de Santa Maria.

\section{Depois da batalha}

Desde cedo, a batalha de Las Navas de Tolosa foi interpretada como um acontecimento, a todos os títulos, excecional, em larga medida devido às avultadas baixas sofridas pelo exército derrotado, mas também por se tratar da primeira vitória alcançada em batalha campal sobre os Almóadas. Não é, pois, de admirar que alguns autores coevos tenham interpretado o episódio de 16 de julho de 1212 como algo de verdadeiramente transcendente e de carácter decisivo, ou seja, como algo que vinha assinalar 
o final do domínio almóada na Península Ibérica e, em última análise, o fim do próprio Império (García Fitz, 2008: 538-539; García Fitz, 2011: 51 e ss; e Alvira Cabrer, 2012: 471-509). Esse era, aliás, um ponto de vista partilha169 do tanto por cristãos (por exemplo, Rodrigo Jiménez de Rada) como por muçulmanos (sobretudo Ibn-Abi-Zar), não só nos anos que se seguiram à batalha como ainda mais de um século depois (Rodrigo Jiménez de Rada, Livro VIII, cap. X; e Ibn-Abi-Zar, p. 537).

Consequentemente, a historiografia europeia - e em particular a espanhola - acabou por seguir de perto esta abordagem, apresentando a batalha como o final de um ciclo e um momento de inflexão na relação de forças existentes na Península Ibérica, ou seja, como uma batalha que veio acelerar o fim da presença muçulmana na Península (García Fitz, 2008: 539541; e Alvira Cabrer, 2012: 468-469), perspetiva partilhada ainda hoje pela esmagadora maioria dos historiadores - nomeadamente medievalistas ensaístas e divulgadores (García Fitz, 2011: 52 e 54-56).

Porém, como tem vindo a ser demonstrado desde meados do século XX pelos estudos de Ambrosio Huici Miranda - a contra corrente do que, até aí era comum afirmar-se — Las Navas não foi, de modo algum, uma batalha decisiva, nem sequer o momento em que se desvaneceram as últimas esperanças que o Islão tinha de consolidar a sua presença na Península Ibérica, e muito menos o início de uma nova fase da Reconquista. Com efeito, segundo aquele autor, mesmo que o desfecho da batalha tivesse sido outro, dificilmente o avanço dos reinos cristãos para sul seria travado, tal como seria impossível evitar a desagregação e o fim do império almóada, já que isso foi o resultado, não da derrota averbada em Las Navas, mas sim de questões relacionadas, por um lado, com a sua grande extensão territorial e com a instabilidade do próprio movimento político-religioso fundado por Ibn-Tumart e, por outro, com o surgimento, no Norte de África, de um poder concorrencial: o dos Benimerines (pp. 277-278).

Mais recentemente, Francisco García Fitz retomaria algumas destas questões, desenvolvendo-as em diversos dos seus estudos e analisando-as à luz do conceito de "batalha decisiva", concluindo também que Las Navas não foi, de forma alguma, uma batalha com essas características. 
Em primeiro lugar, porque nem o poder político-militar almóada foi afetado pelo seu resultado nos anos que se seguiram, nem o ritmo de conquistas 170 levadas a cabo pelos reinos cristãos foi alterado; e, em segundo lugar, porque o prélio "não foi determinante na resolução final do conflito entre cristãos e muçulmanos na Península" (2008: 541-542; e 2011: passim).

De facto, ao contrário do que seria expectável, nos anos que se seguiram a Las Navas não se assistiu a um recrudescimento da atividade militar por parte das monarquias cristãs peninsulares. Na realidade, ainda em 1212, os Almóadas lançam - por iniciativa dos governadores de Jaén e de Córdova-Granada - uma vigorosa ofensiva contra os castelos que guardavam as rotas de travessia da Sierra Morena e recuperam ainda as praças-fortes de Las Cuevas de Garandén e de Alcalá del Júcar, sinal de que poderia estar iminente uma grande campanha contra o território castelhano. E apesar de Afonso VIII conseguir, pouco depois, reconquistar aquelas duas praças-fortes e tomar ainda diversos castelos na região de La Mancha, a ameaça almóada estava longe de se encontrar anulada, como bem demonstraram os ataques, em 1213, contra as imediações de Toledo e as derrotas infligidas às milícias concelhias de Talavera durante uma incursão dirigida contra o alfoz de Sevilha.

No entanto, quer castelhanos, quer Almóadas, debatiam-se com sérios problemas internos — os primeiros com profundas dissensões no seio da nobreza e com um ciclo de maus anos agrícolas, os segundos com a morte de al-Nasir e a sucessão de seu filho, Abu Yaqub Yusuf II, al Mustansir, ainda menor de idade —, motivos que levaram à assinatura de tréguas em inícios de 1214, renovadas em 1221 e que vigoraram até 1224. Encerravase, dessa forma, um período de dois anos profundamente marcado, quer de um lado, quer do outro, pelos efeitos da campanha e da batalha de Las Navas. Trata-se do final de um ciclo assinalado também pela morte de alguns dos seus protagonistas. Primeiro, al-Nasir e Pedro II de Aragão, ambos em 1213; depois, Afonso VIII, em outubro de 1214. O momento de viragem que tantos fazem remontar a 1212 surgiria apenas com o final das tréguas, em 1224, precisamente no ano da morte do califa al Mustansir e da implementação, por Fernando III, de uma estratégia assumidamente ofensiva contra o império almóada. 
Mesmo sem se afirmar como um momento decisivo, nem por isso Las Navas deixa de ser uma das mais importantes batalhas da História da Idade Média peninsular. De facto, é o momento alto de uma campanha desencadeada, logo desde o seu início, com um objetivo singular: o de enfrentar e derrotar o inimigo em batalha campal; além disso, conseguiu reunir três reis e um califa, bem como contingentes de várias proveniências, possibilitando - o que era igualmente raro - a mobilização de um número invulgarmente elevado de efetivos, tanto de um lado quanto do outro. Mas a importância de Las Navas expressa-se ainda a outros níveis. Como notava, em meados do século XX, Ambrosio Huici Miranda, o triunfo cristão na campanha de 1212 permitiu avançar a fronteira - praticamente imutável desde a conquista de Toledo, em 1085 - desde o vale do Tejo, fixando-a a sul da Sierra Morena, em plena Andaluzia (2000: 277-278). Além disso, conforme relembraram García Fitz e Martín Alvira, foi a campanha de 1212 que veio assegurar a posse, em mãos castelhanas, de algumas das principais fortalezas situadas entre Toledo e a Sierra Morena, convertidas agora em bases operacionais para campanhas futuras, nomeadamente para o avanço definitivo, já no reinado de Fernando III (1217-1252), em direção ao coração da Andaluzia, isto é, a caminho de Sevilha (García Fitz, 2008: 544-545; e Alvira Cabrer, 2012: 476-478). 


\section{Fontes mais importantes}

172 - "Carta de Afonso VIII ao papa, participando o resultado da batalha", publicada por Julio González, El Reino de Castilla en la Época de Alfonso VIII, Madrid, 1960, Vol. II, doc. 897, pp. 566-572.

— Rodrigo Jiménez de Rada, Opera Omnia. Pars I: Historia de Rebus Hispaniae sive Historia Gothica, ed. de Juan Fernández Valverde, Corpus Christianorum. Continuatio Medievalis, LXXII, Turnhout, 1987.

— "Carta de Arnau Amalric ao capítulo da Ordem de Cister", publicada e traduzida por Maria Dolores Rosado Llamas y Manuel Gabriel López Payer, Las Navas de Tolosa. Historia y Mito, Jaén, 2001, pp. 329-333.

- "Carta do califa al-Nasir sobre a batalha de Las Navas", publicada por Maria Dolores Rosado Llamas y Manuel Gabriel López Payer, Las Navas de Tolosa. Historia y Mito, Jaén, 2001, pp. 333-335.

— "Carta de D. Berenguela a sua irmã Branca, dando conta do desfecho da batalha", publicada por Julio González, El Reino de Castilla en la Época de Alfonso VIII, Madrid, 1960, Vol. II, doc. 898, pp. 572-574.

- "Carta de Branca de Castela a Branca de Champagne, dando conta do desfecho da batalha", publicada e traduzida por Maria Dolores Rosado Llamas y Manuel Gabriel López Payer, Las Navas de Tolosa. Historia y Mito, Jaén, 2001, pp. 337-338.

Juan de Soria, Cronica Latina de los Reyes de Castilla, ed. de Luis Charlo Brea, Cádiz, 1984. Lucas de Tuy, Chronicon Mundi, ed. de E. Falque, Turnhout, Brepols, 2003.

Primera Crónica General de España, ed. de Ramón Menéndez Pidal, Madrid, Editorial Gredos, 1977, Tomo II.

Crónica de Veinte Reyes, ed. de César Hernández Alonso, Burgos, 1991.

Ibn-Abi-Zar, Rawd al-Qirtas, trad. de Ambrosio Huici Miranda, Valencia, 1964, vol. II (2ª edição). 


\section{Leituras Principais}

Ambrosio Huici Miranda - Las Grandes Batallas de la Reconquista Durante las Invasiones

Africanas, Edição Facsimilada da edição de 1956, Granada, Editorial Universidad de Granada, 2000.

Francisco García Fitz - Las Navas de Tolosa, Barcelona, Ariel, 2008 (ed. orig.: 2005).

Martín Alvira Cabrer — Las Navas de Tolosa. 1212. Idea, Liturgia y Memoria de la Batalla, Madrid, Sílex, 2012.

\section{Leituras complementares}

Bernard Reilly, Cristãos e Muçulmanos. A Luta pela Península Ibérica, Lisboa, Teorema, 1996.

Carlos Vara Thorbeck, El Lunes de Las Navas, Jaén, s.n., 1999.

F. Xavier Hernàndez Cardona, Història Militar de Cataluyna. Aproximació Didàctica, Vol. II: Tiempos de Conquesta, Barcelona, 2002.

Ferdinand Lot, L'Art Militaire et les Armées au Moyen Age en Europe et dans le Proche Orient, Tomo 2, Paris, 1946.

Francisco García Fitz, "Las Navas de Tolosa, un punto de inflexión en las dinâmicas históricas peninsulares?", in 1212-1214: El Trienio que Hizo la Europa - XXXVII Semana de Estudios Medievales - Estella, Pamplona, Gobierno de Navarra, 2011, pp. 47-84.

Francisco García Fitz, "El año de la batalla de Las Navas de Tolosa", in 1212, un Año, un Reinado, un Tiempo de Despegue - XXIII Semana de Estudios Medievales, Coord. de Esther López Ojeda, Logroño, Instituto de Estudios Riojanos, 2013, pp. 171-200.

Inês Lourinho, 1147. Uma Conjuntura Vista a Partir das Fontes Muçulmanas, Lisboa, Faculdade de Letras da Universidade de Lisboa (Dissertação de Mestrado, policopiada), 2010.

J. E. Ruiz Doménech, "El significado historic de la Batalla de Las Navas de Tolosa y sus consecuencias", in La España de los Cinco Reinos (1085-1369), Historia General de España y América, Vol. IV, coord. de Miguel Ángel Ladero Quesada, 1984, pp. 585-589.

James F. Powers, "Las Navas de Tolosa", in The Oxford Encyclopedia of Medieval Warfare and Military Technology, Vol. 2, ed. de Clifford J. Rogers, Oxford, Oxford University Press, 2010, pp. 489-491. 
João Gouveia Monteiro, "A Arte Militar na Europa dos Séculos XI-XIII — Um Vade Mecum", in Revista de História das Ideias, Vol. 32, Coimbra, 2011, pp. 7-49.

174 Kelly DeVries, "Las Navas, 1212", Battles of the Crusades, 1097-1444 — From Dorylaeum to Varna, London, Amber Books, 2007, pp. 148-157.

María Jesús Viguera Molíns, Los Reinos de Taifas y Las Invasiones Magrebies, Madrid, Mapfre, 1992.

Martín Alvira Cabrer, Guerra e Ideología en la España Medieval: Cultura y Actitudes Históricas ante el Giro de Princípios del Siglo XIII. Batallas de Las Navas de Tolosa (1212) y Muret (1213), Madrid, Universidad Complutense, 2000 (Dissertação de Doutoramento, policopiada).

Philip Morgan, War and Society in Medieval Cheshir, Manchester, Chetham Society, 1987.

Philippe Contamine, War in the Middle Ages, Oxford (UK) / Cambridge (US), Blackwell, 1996.

Rafael Peinado Santaella, "El Pastor de las Navas o trampa ideologica de una imagen de Cruzada", in La Literatura no ha existido siempre. Para Juan Carlos Rodríguez, Granada, 2015, pp. 439-453. 


\section{Etapas da Reconquista}

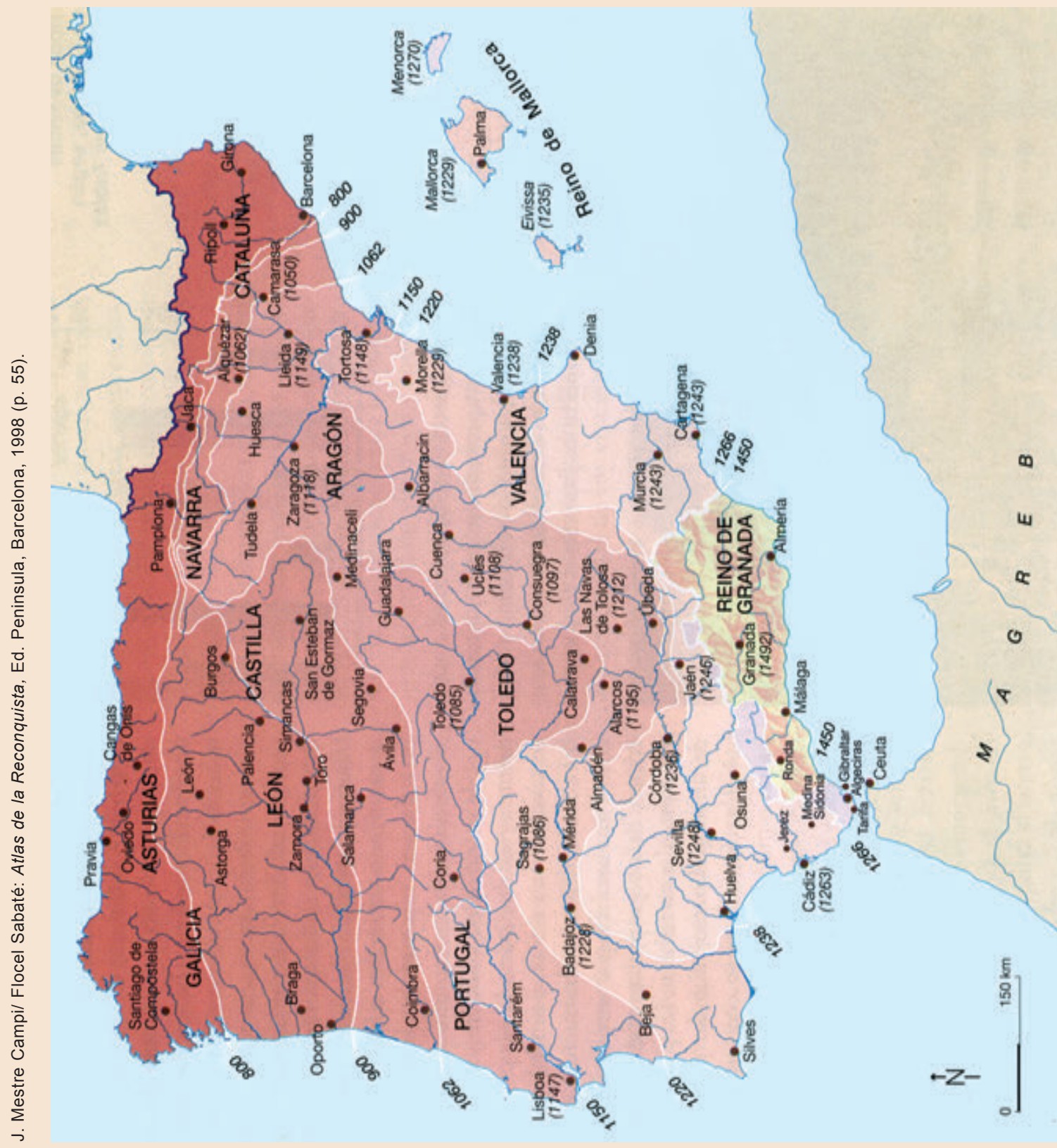



Las Navas de Tolosa, 1212 | Itinerários dos exércitos
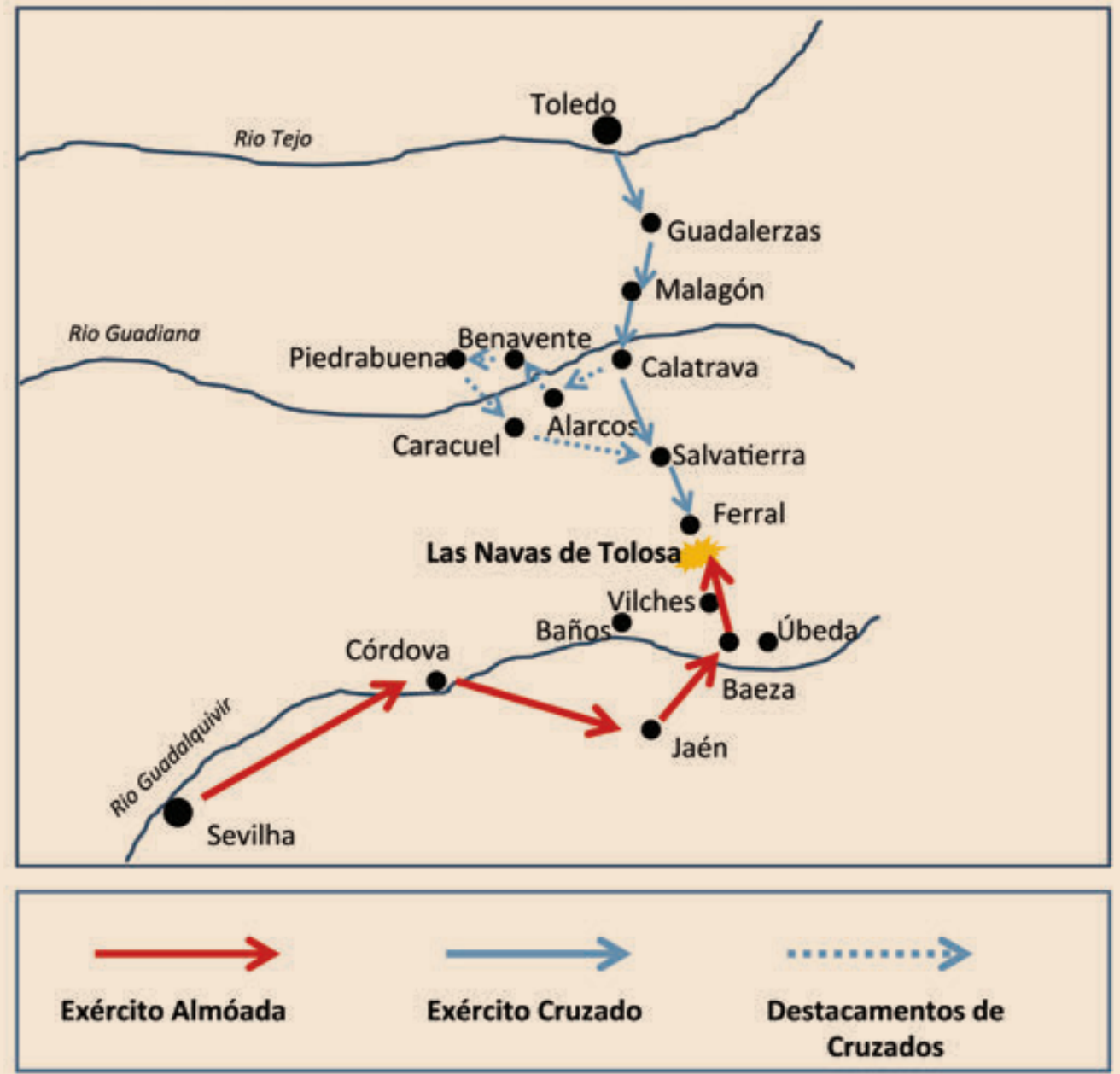


\section{Momentos da Batalha | 1}
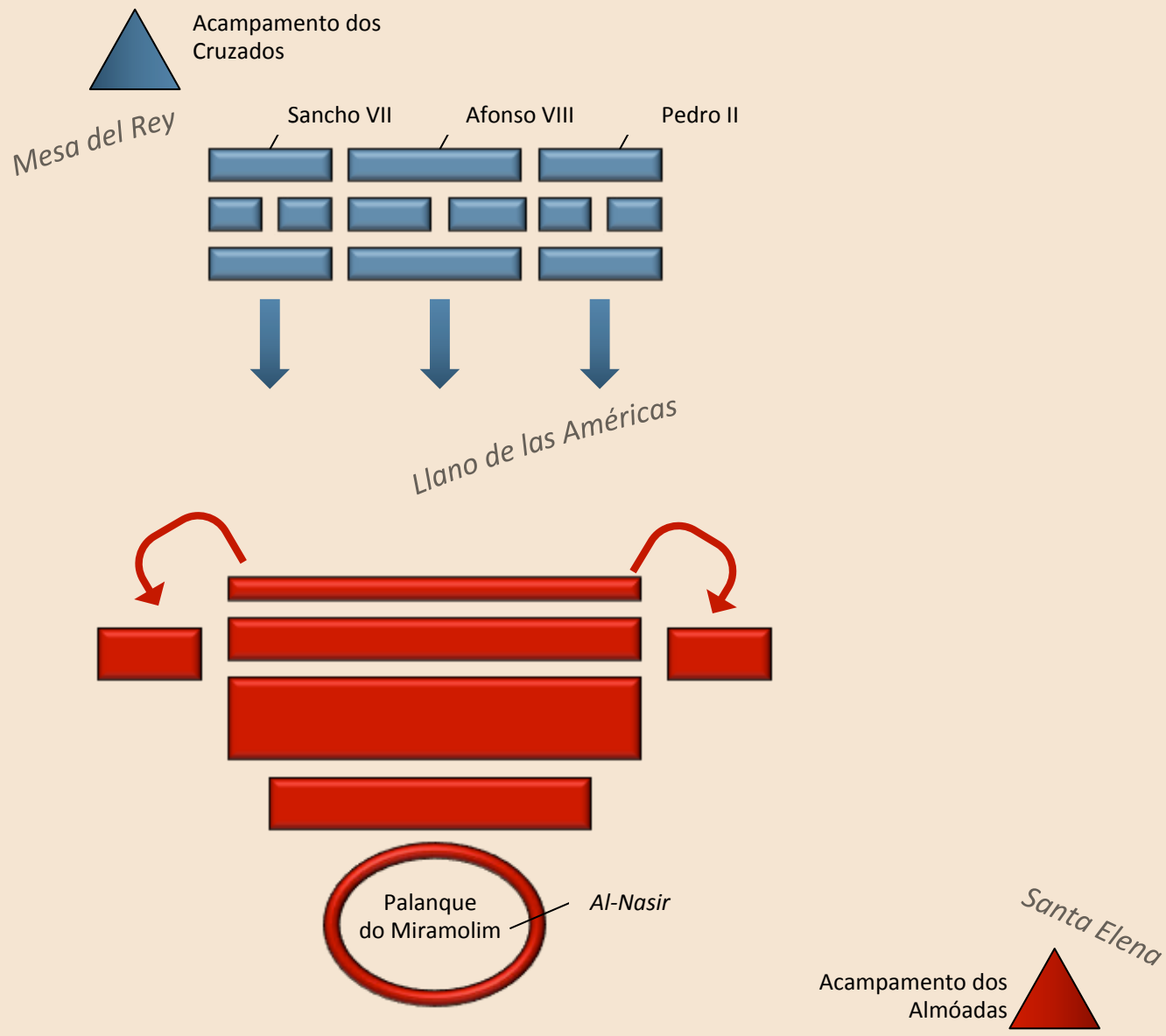


\section{Momentos da Batalha | 2}
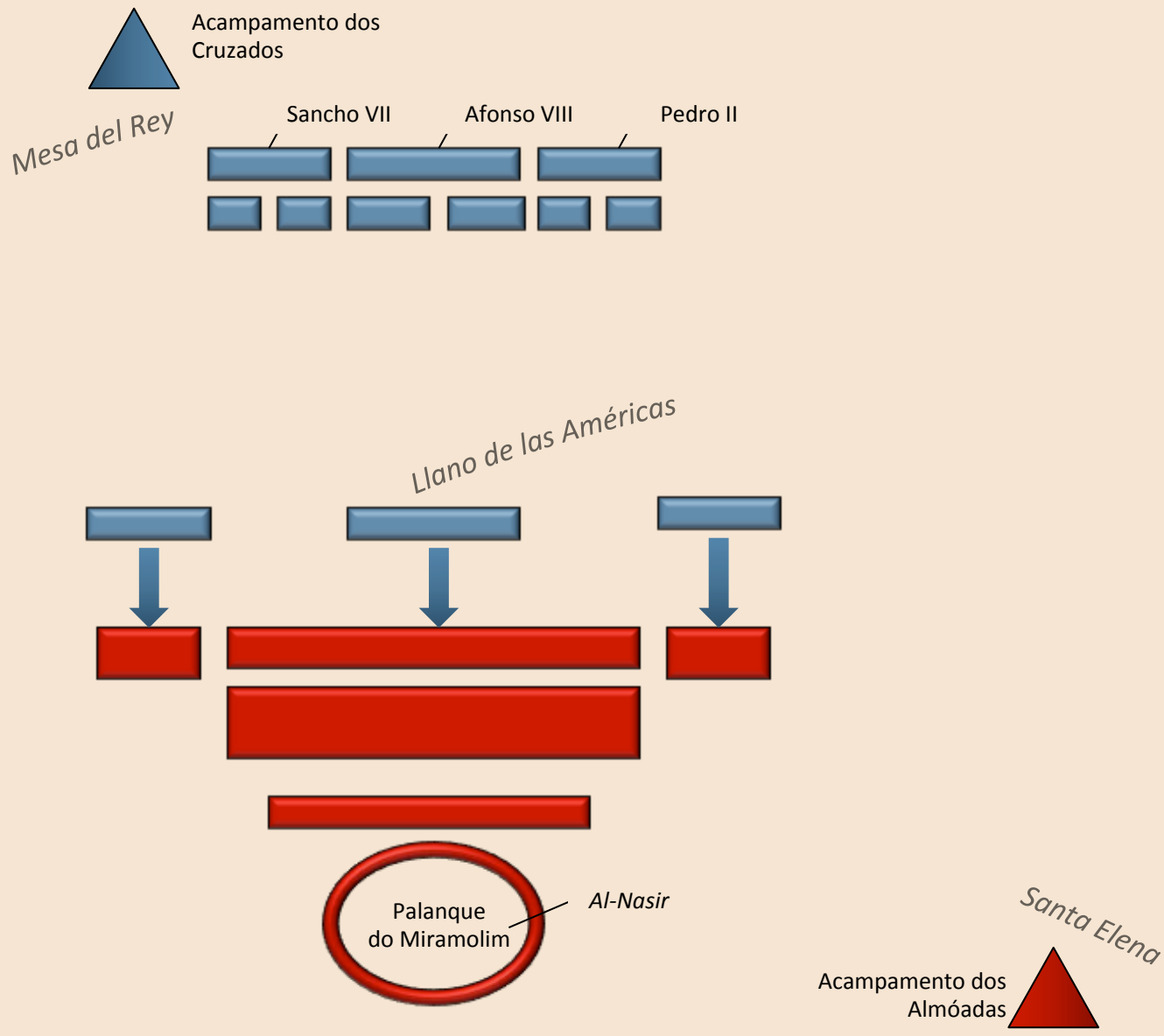

Miguel Gomes Martins, 2015 


\section{Momentos da Batalha | 3}
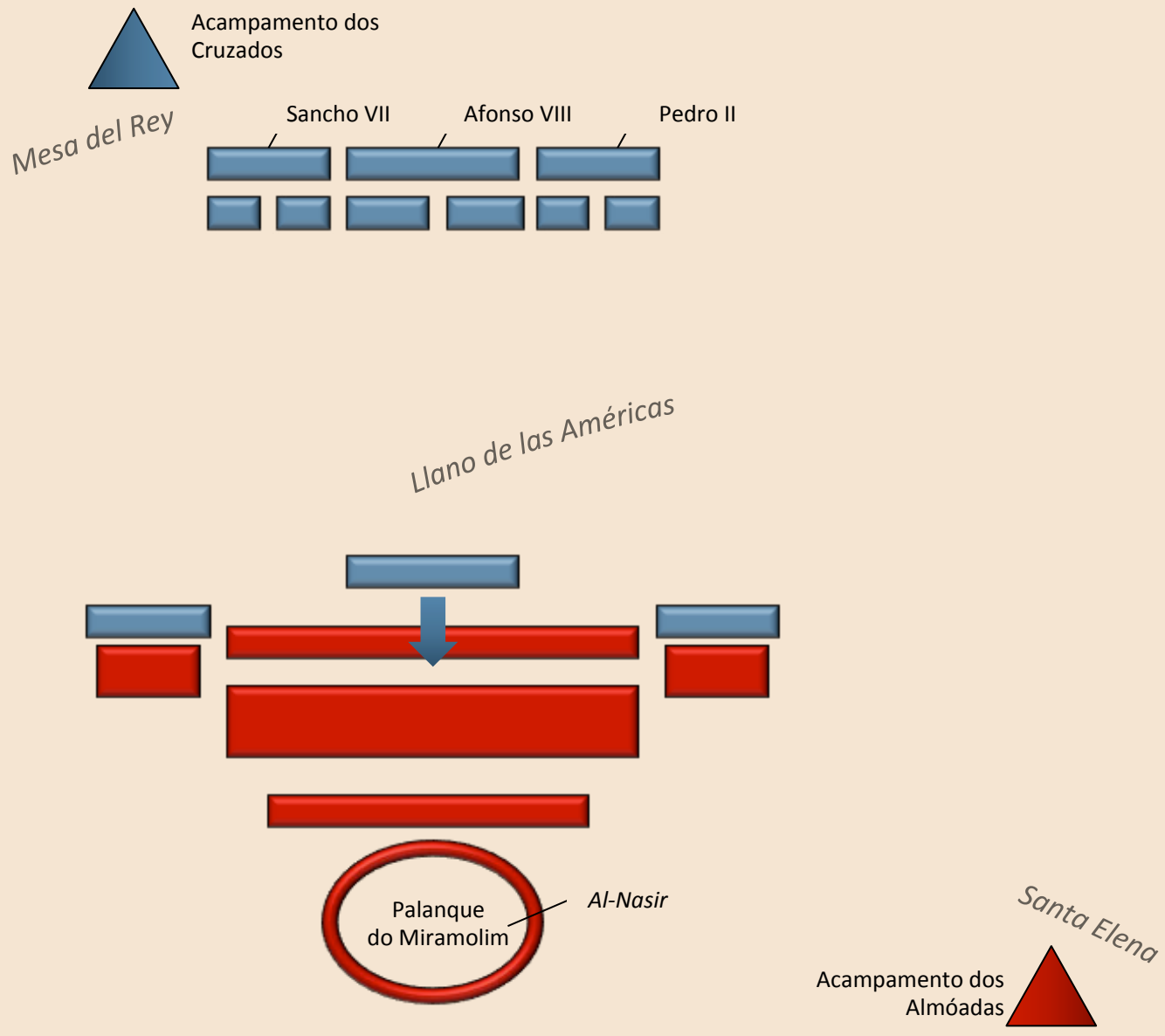

Miguel Gomes Martins, 2015 


\section{Momentos da Batalha | 4}
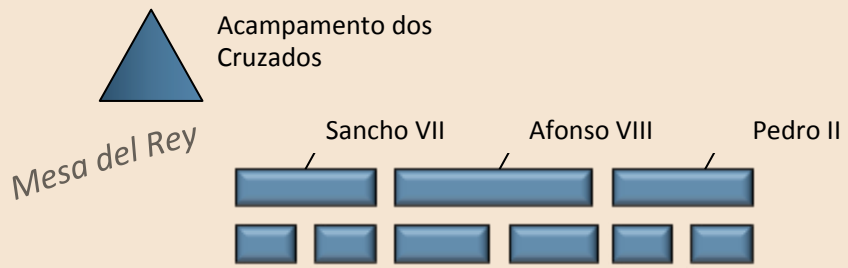

$$
\text { Llano de las Américas }
$$
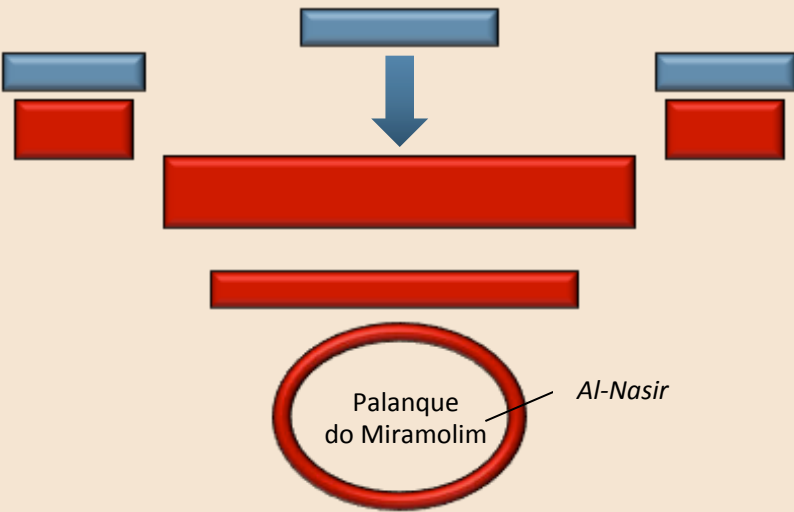

Acampamento dos Almóadas 


\section{Momentos da Batalha | 5}
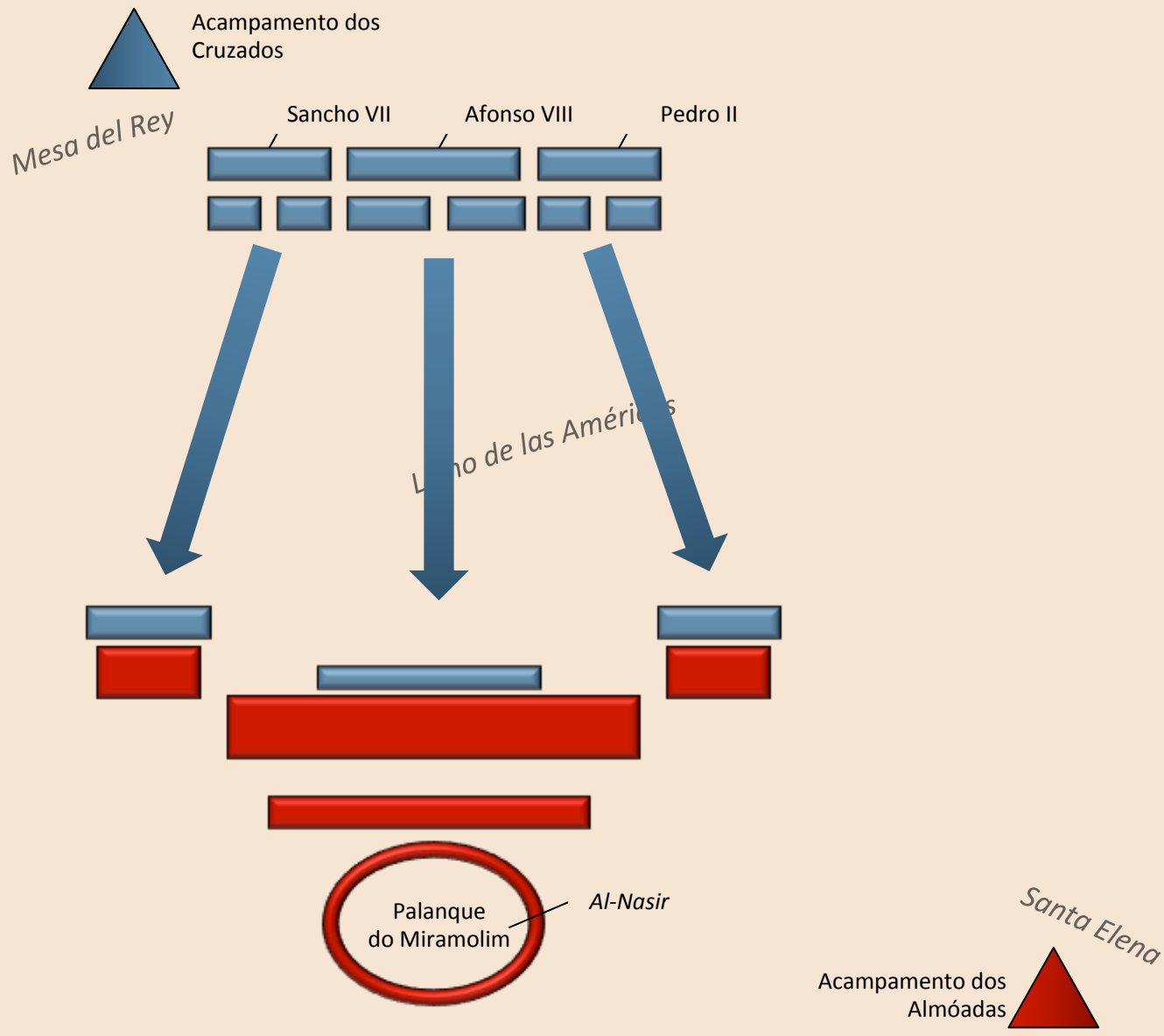

Miguel Gomes Martins, 2015 


\section{Momentos da Batalha | 6}

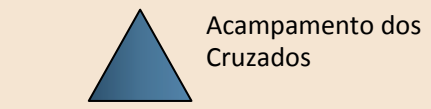

Mesa del Rey Sancho VII, Afonso VIII, Pedro II

$$
\text { Llano de las Américas }
$$
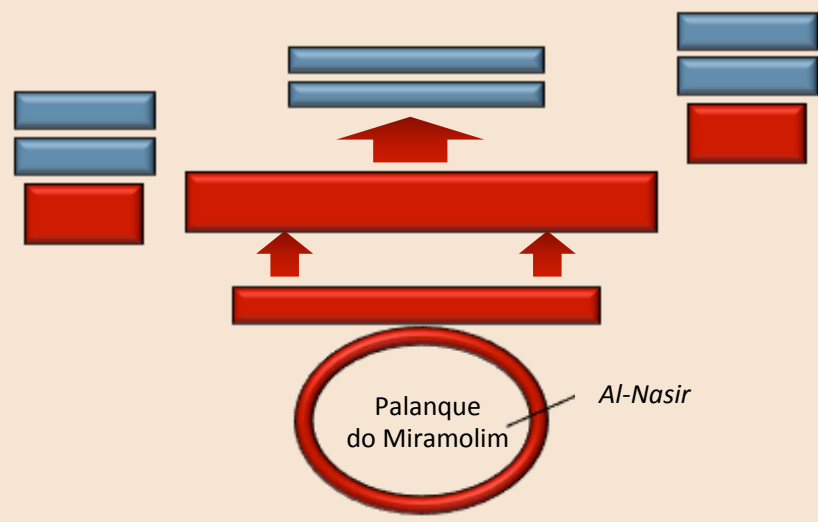

Acampamento dos Almóadas 


\section{Momentos da Batalha | 7}
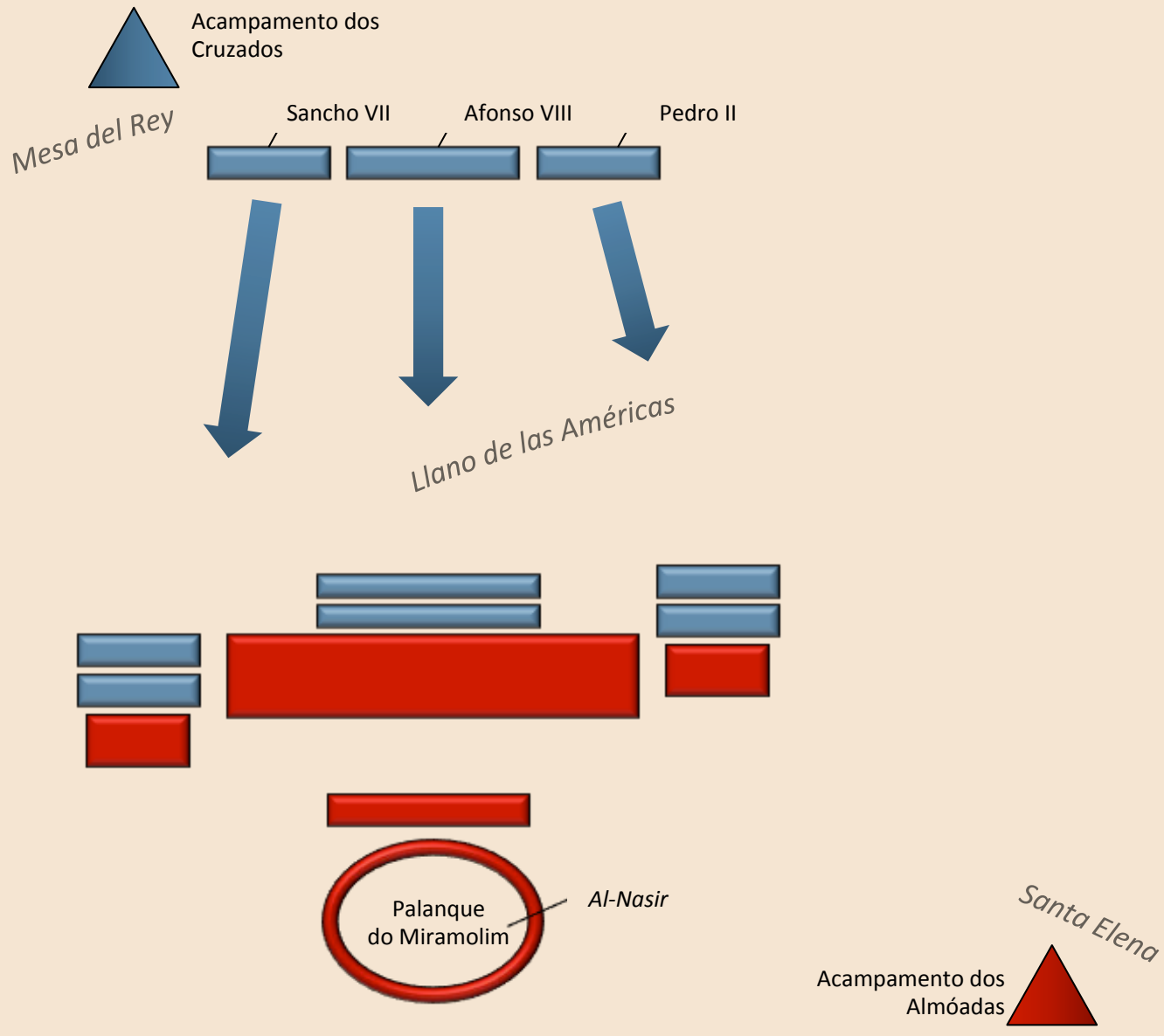

Miguel Gomes Martins, 2015 


\section{Momentos da Batalha | 8}

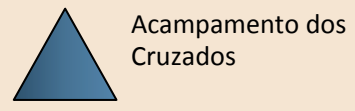

Mesa del Rey
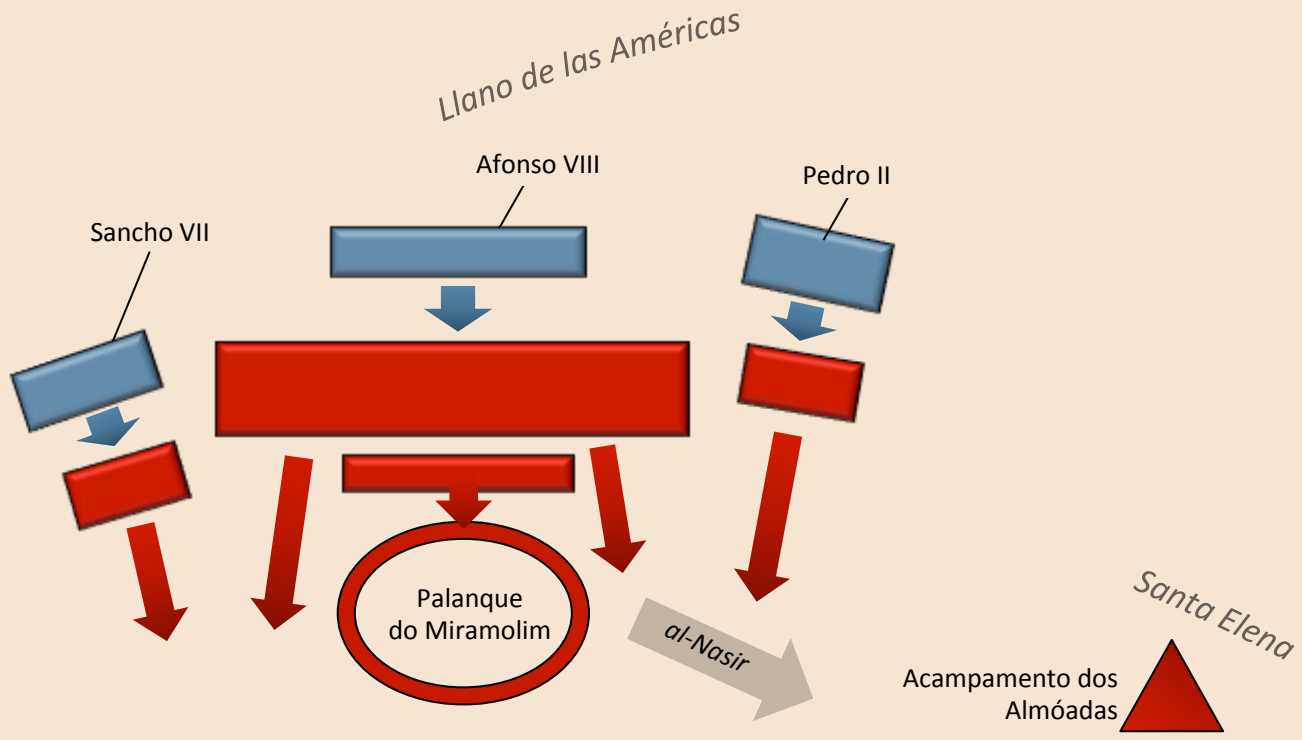

Miguel Gomes Martins, 2015 


\section{Momentos da Batalha | 9}

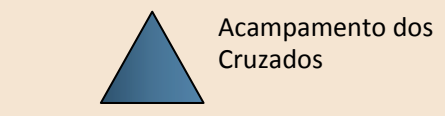

Mesa del Rey

$$
\text { Llano de las Américas }
$$

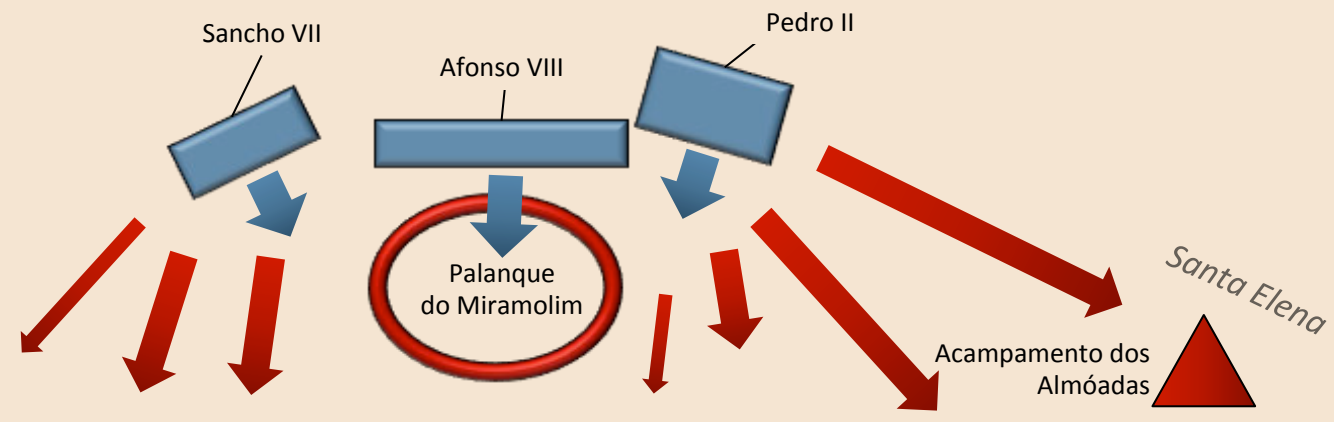

Miguel Gomes Martins, 2015 

Resumo dos momentos da batalha
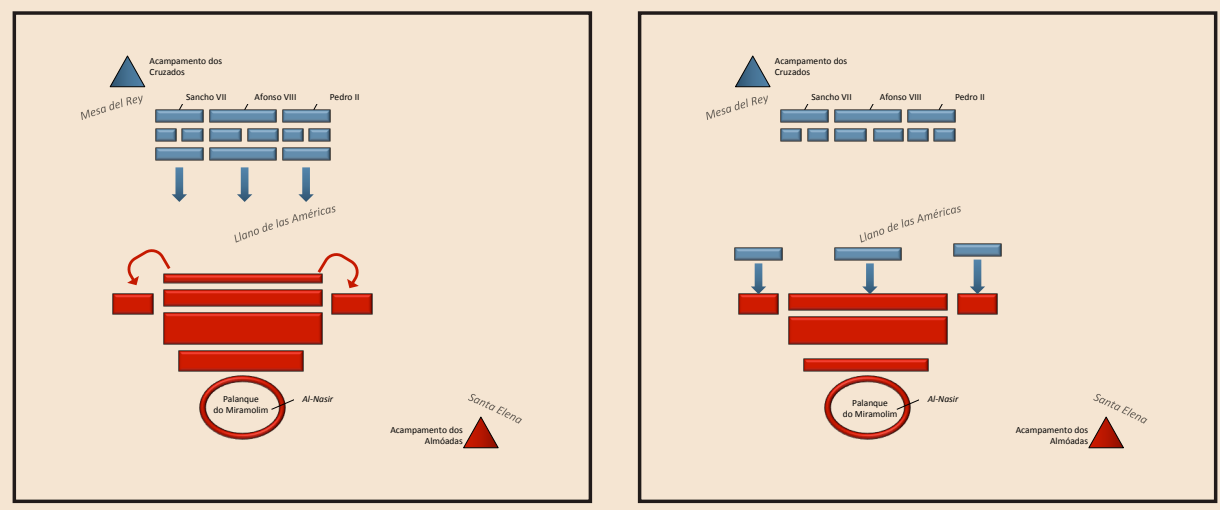

1

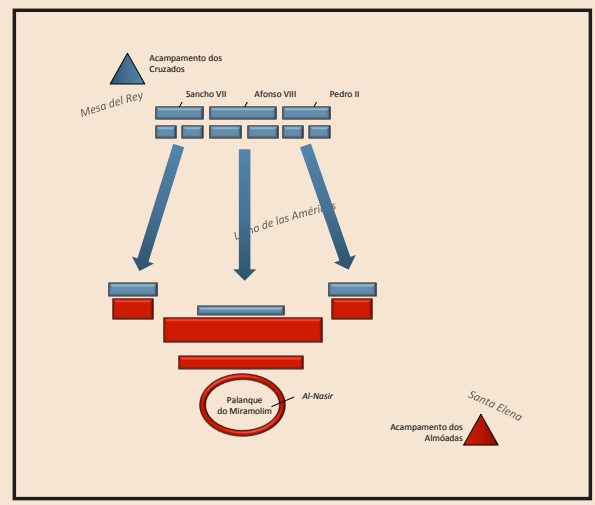

5

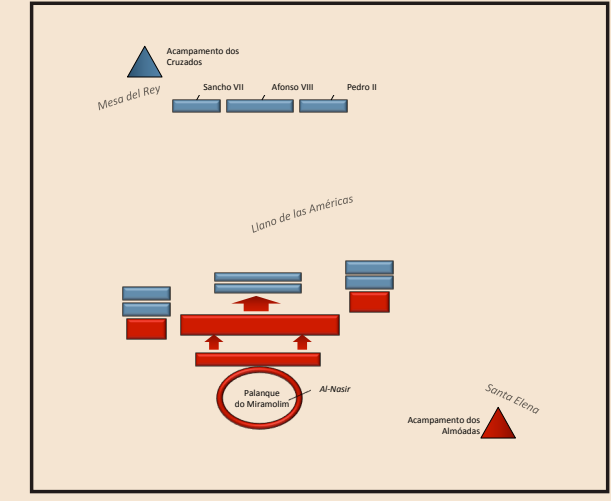

6

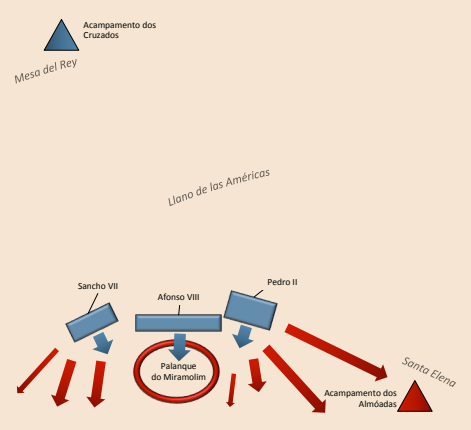

9 


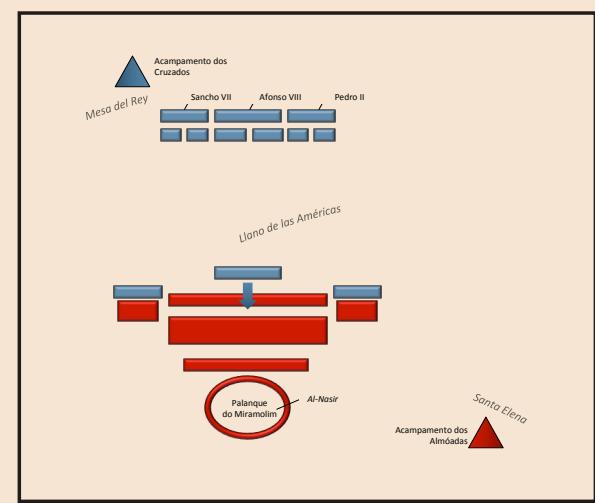

3

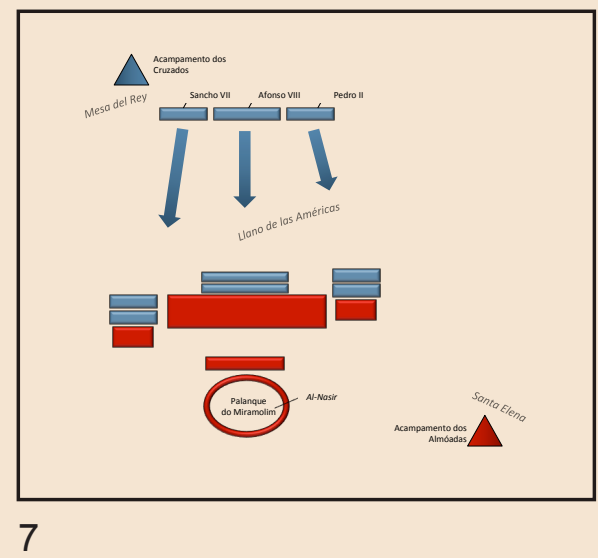

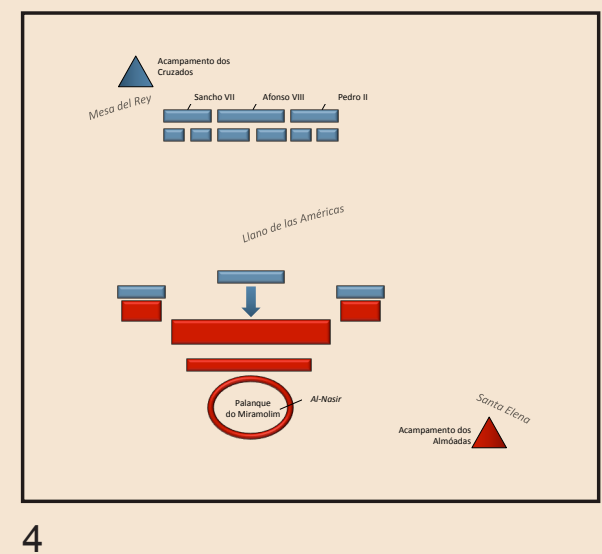

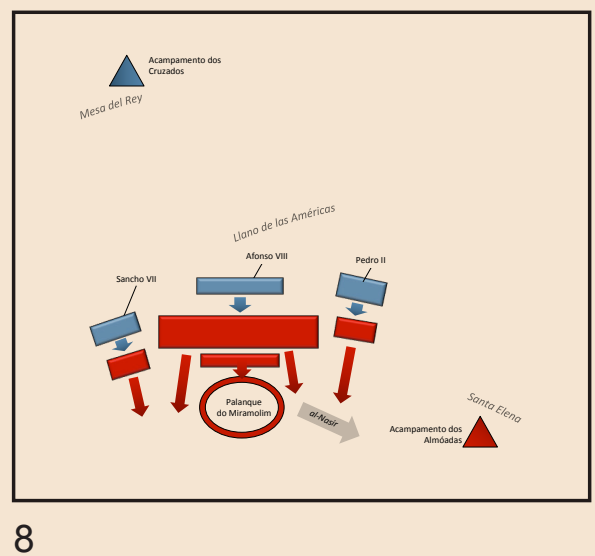




\section{Série Investigação}

\section{Imprensa da Universidade de Coimbra}

Coimbra University Press

2015

- $\mathrm{U}$

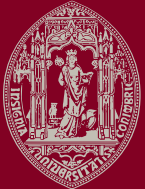

C •

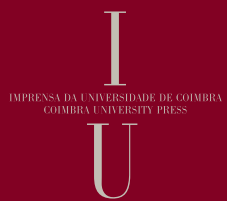

